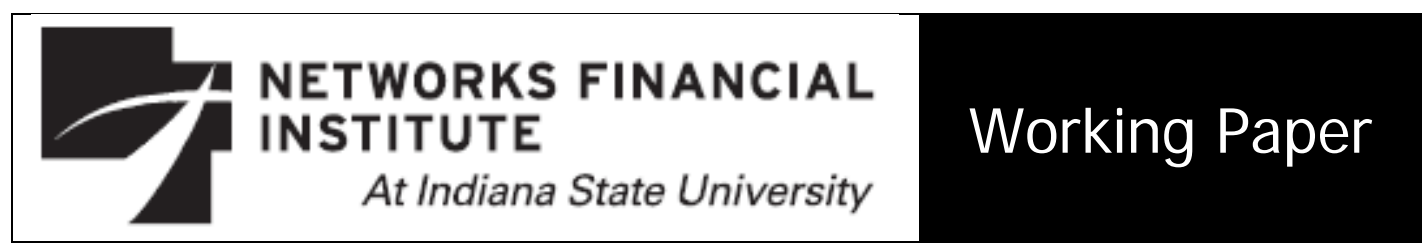

2018-WP-03 - March 2018

\title{
Ownership structure and bank risk: The effects of crisis, market discipline and regulatory pressure
}

\author{
Viet-Dung Tran, M. Kabir Hassan, and Reza Houston
}

Abstract: Using a large panel of US BHC over the 2001:Q1-2015:Q4, we investigate the risk-taking behaviors of banks within a comparison perspective - between public and private banks - where there exists substantial differences of asymmetry information and agency problems. We document evidence of greater stability of public banks versus their private peers. However, public banks become riskier than private banks during the last crisis. These findings suggest a mixed evidence of risk-taking mitigating role of listing status. Regulatory pressure is effective in limiting risk taking by undercapitalized public banks before, but not during the crisis, casting doubt the effectiveness of regulators during the turmoil times. Public banks with high franchise value expose to risk less than others during the crisis. Debtholders discipline is ineffective in curbing the risk-taking behavior of banks. Our study is of interest for regulators, policymakers who are in search of improving bank risk-taking behavior.

About the Authors: Viet-Dung Tran is affiliated with the Center for Studies and Applied Research in Management (CERAG) and Université Grenoble Alpes. He pursues research on the capital structure of Vietnamese banks. M. Kabir Hassan is Professor of Finance in the Department of Economics and Finance in the University of New Orleans. He currently holds two endowed Chairs-Hibernia Professor of Economics and Finance, and Bank One Professor in Business- in the University of New Orleans. Professor Hassan is the winner of the 2016 IDB Prize in Islamic Banking and Finance. Professor Hassan received his M.A. in Economics and Ph.D. in Finance from the University of Nebraska-Lincoln, USA respectively. Reza Houston is Assistant Professor of Finance and the Research Director of the Networks Financial Institute. Reza holds a Ph.D. in finance from the University of Missouri, and an MBA from Indiana State University. He has served as a journal referee, presented numerous papers, and acted as a discussant at international conferences. He currently maintains research interests in the role of the political economy, credit risk, and mergers and acquisitions.

Keywords: bank listing status; risk taking; crisis; market discipline; regulatory pressure

\section{J EL classification: G21, G28, G34, G38}

The views expressed are those of the individual author and do not necessarily reflect official positions of Networks Financial Institute. Please address questions regarding content to Viet-Dung Tran at vietdung.tran@upmf-grenoble.fr. Any errors or omissions are the responsibility of the author. NFI working papers and other publications are available on NFI's website (www. networksfinancialinstitute.org). Click "Publications" 


\section{Introduction}

It is widely accepted that the excessive risk-taking by banks is one of the main contributions of the recent financial crisis, which in turn cause the subsequent economic recession. Managers increase the risk-taking of banks with the purpose to increase the shareholder value of the implicit government guarantees. When everything runs normally, banks enjoy their excessive risk-taking. However, when economics go down, they are financially distressed. The regulators, fearing a cascade of bank failures, step in and rescued banks, which in turn may have negative effects on discipline forces of the markets.

In this paper, we analyze the relationship between the bank's ownership structure and their risk taking. In particular, we assess whether the listing status acts as a mitigating tool or an exacerbating mechanism of risk taking in banking firms. Our main conjecture is related to the greater asymmetric information and agency costs exhibited by public banks to compare with private banks, due to a greater difference in control and access to the capital markets, which in turn implies important heterogeneity on the shape banks’ risk profile.

One may argue that public banks have higher incentive to engage risk taking than private banks due to higher agency problems. Under a more diffused ownership structure, shareholders of public banks are more likely use simple low-cost heuristics to assess and monitor bank risk, whereas shareholders of private banks may closely monitor bank management thanks to fairly rich information. In addition, public banks may face higher pressures from the capital markets to report high short-term performances. Finally, the compensation of managers that relies on bank stock performances may also induce higher risk-taking in public banks. These arguments suggest public banks exert more risk taking than private banks (The opportunistic hypothesis).

However, public banks may be less risky than private banks due to the discipline forces from the capital markets and managerial labor markets. The signals from the markets would allow the risk-sensitive security holders to accurately assess bank risk properties, and to adjust the price of securities. The securities holders can force banks back toward the adequate level of risks they would choose, lowering the potential agency problems and risk taking of banks. Furthermore, being listed facilitates the regulators for controlling banks since information of public banks is upto-date, and more readily, leading to a faster reaction of regulators. In addition, public banks have greater franchise value from the access to the capital markets, and are covered by external monitors of management such as financial analysts or rating agencies. These characteristics may mitigate 
the risk taking behaviors of public banks. Another point is that managers who naturally are less diversified than shareholders, will tend to be conservative in risk taking to secure their human capital, to protect their reputation and to avoid losing their job. These arguments suggest that public banks may be less risky than private banks (The monitoring hypothesis).

In this paper, we examine the interplay of listing status and bank risk for a large sample of US public and private bank holding companies (BHC) from 2000:Q1 to 2015:Q4. We use ZSCORE as our main proxy for bank risk. A bank with high ZSCORE have high distance from default, hence lower risk. Controlling for the effects of different bank characteristics and time effects, our empirical analysis provides consistent evidence of lower risk of public banks versus their private peers, consistent with our monitoring hypothesis. The evidence is economically significant. For example, the result from our baseline model indicates that ZSCORE of public banks are on average 7.680 higher than ZSCORE of private banks, with other independent variables held at their means. Based on the average ZSCORE of private banks of 42.060, this coefficient is economically important since it implies that ZSCORE is about $18.3 \%$ higher for public banks, compared to private banks. These findings reject the opportunistic hypothesis that the agency problems derived from the separation of ownership and control would make public banks become riskier than their private peers, and support the monitoring hypothesis that the pressure from capital markets and other external agents would lead public banks less risky. The results could be considered as the net effect of the reduced agency problems and the increased monitoring from external agents.

Having established the higher risk of private banks versus public banks, we further investigated how the risk profile of public banks should change were they a private bank. We find that public banks would become riskier if they were the same bank but private.

To ensure the strength of our findings, we provide a battery of sensitivity tests. First, we re-perform our analysis with additional variables to deal with the concerns of potential omitted variables, with alternative measures of risk, with alternative sampling, especially for the concern of the bank size. In all specifications, we obtain similar finding, which is public banks exhibit higher ZSCORE than private banks.

Second, we use different econometric approaches to make sure that our results are robust. We start with the quantile regression. We document that the impacts of listing status on bank risk are indeed uniform in sign (positive), but increased significantly in magnitude with the increase of 
quantiles. This evidence indicates that listing status does not only affect the conditional average ZSCORE, but also influences the ZSCORE dispersion. We also perform Newey-West, PraisWinsten Fama-MacBeth and two-way clusters procedures. In all specifications, our findings remain unchanged.

We address the concern related to potential endogeneity in the decision to go public, which is a deliberate decision by bank managers. We begin with the propensity score matching, to dissipate potential explanations that our findings reflect differences in the characteristics of public and private banks. Then we use the Heckman two-step model and an instrumental variables approach to extract the private information of the decision to go public that could be correlated with the propensity to use discretion in financial reporting. ${ }^{1}$ In all specifications, our findings remain unchanged. We also deal with endogeneity concern with the examination of the change of bank risk after the transition of ownership status. We document that private banks become less risky after going IPO, and public banks become riskier after going private. These findings although related to a fraction of banks with change in ownership structure, are consistent with the monitoring hypothesis, and cast doubt the Jensen (1986)'s suggestion on going private to reduce the agency costs.

Next, we investigate whether listing status affects bank risk differently during financial crises or not. First, we compare risk profile of each type of banks (i.e. private and public) during the crisis taking into account the bank characteristics of the pre-crisis period. We document that both types of banks become riskier during the crisis, especially for public banks. Next, we perform regression analyses to have a better understanding on the effects of the crisis. The results suggest that public banks become riskier during the crisis than private banks. The evidence suggests that the monitoring forces from the markets are outweighed by the agency costs from the greater separation of control, and casts doubt of the risk-taking mitigating role of listing status during crisis.

We then go further by assess how the market discipline and regulatory pressures can alter the interplay of listing status and bank risk. We find that during the crisis, public banks with high franchise value will lower their risk-profile. Interestingly, this mitigating role of deposit franchise value appears only during the crisis, since we do not observe any relation during the normal times. We do not find any discipline effect from the (subordinated) debt markets on the risk taking

\footnotetext{
${ }^{1}$ We also perform the system GMM, and still find similar findings.
} 
behavior of our bank sample, neither during the normal or crisis times. Finally, we observe that public banks subject to high regulatory pressure are riskier during the crisis whereas those banks are less risky during the normal times. This evidence casts doubt the effectiveness of regulators during the last crisis.

Our study contributes to the literature in several ways. First, our study extends the currently limited debate on risk taking behavior between public and private banks. We document lower risk in public banks than private banks. In a concurrent paper, Samet, Boubakri, and Boubaker (2018) with their international sample also document a lower risk in public banks versus private banks. Our study focuses on a single country, alleviating the endogeneity issue associated with crossborder research, since the decision to go public or private and the financial reporting quality could be jointly determined by country- and institutional-level characteristics such as securities regulations and disclosure rules (Kim and Yi, 2006, Tran, Hassan, and Houston, 2018). Imposing these limitations makes our evidence stronger, cleaner, and more robust. Furthermore, in contrary with Samet, Boubakri, and Boubaker (2018), our study deal carefully with the endogeneity concerns with difference approaches from matching procedures to instrumental variables approaches. We also compare the riskiness of banks that undergo a change in ownership structure. In a similar study, Kwan (2004) also uses US BHC sample as our study, but provides a mixed evidence. The author finds that public banks hold more capital than private banks whereas loan quality and earnings variability are comparable across public and private banks. However, the author only performs the bivariate analysis, hence its findings may be biased by other (observable and unobservable) bank characteristics. Furthermore, the findings of Kwan (2004) is based on the period of 1986-2001, which may be no longer accurate within an industry with full change in policy (e.g. the Gramm-Leach-Billey Act in 1999), in technologies, etc. which may in turn shape different risk-taking incentives in banks.

Second, to the best of our limited knowledge, the study provides one of the first empirical evidence of the effects of listing status over a range of risk distribution. The traditional inference approach (i.e. the ordinary least squares, OLS) describes the average behavior of the sample due to the assumption of the homogenous of the effects of ownership structure on bank risks. However, when the heterogeneity in the sample is important, there may be a poor description from the traditional approach. Rather than relying on a single description of the central behavior of the sample, the quantile approach explores a range of conditional quantile functions, which in turn 
allows us to explore potential forms of conditional heterogeneity. We document the uniform on the effects of the listing status on bank risks, and these effects increase in conditional high ZSCORE.

Third, our paper documents differential risk-taking behaviors of public versus private banks during crisis period which are not investigated in prior literature. We find that public banks become riskier than private banks during the turmoil times, suggesting that the agency problems of a greater separation of control dominate the risk-taking mitigating role of listing status. This finding is not consistent with what Samet, Boubakri, and Boubaker (2018) document in their international evidence, and reinforce the necessity and the timing of our research.

Finally, the study also identifies the variety of settings that could motivate different risk behaviors between public and private banks. The evidence stresses on the mitigating role of (deposit) franchise value on bank risk taking, and also add for the question related to the effectiveness of regulatory pressures during the crisis times.

The next section provides the hypothesis framework. Section 3 describes the data and variables. Section 4 reports the main results and alternative tests. We provide tests related to endogeneity concerns in Section 5. Section 6 provides evidence from the last financial crisis, and the effects of market discipline and regulatory pressure. Section 7 concludes the study.

\section{Why might public and private banks be different in risk taking behaviors?}

Literature points out a separation of residual risk bearing from control of decision-making is essential to the contemporary theory of firms. Shareholders supply capital, hold ultimate control rights, accepts the residual of financial risk in doing business, but receive residual claimants on cash-flow. The decision-marking is however delegated to board of directors that in turn delegate to a management team (Armstrong, Guay, and Weber, 2010). This separation from daily operation control of corporation entails two critical issues: information asymmetry and agency problems (Beatty and Harris, 1999).

On the one hand, the information asymmetry between outsiders and more informed insiders (managers and owned-managers) could prevent outsiders to have a right assessment on true underlying economic performance of "black box", leading to "lemons problem" and consequently costlier external financings. That is, the quality and (suboptimal) quantity of the available information do not allow an efficient resource allocation, thus adversely affect cost of capital, 
which in turn do not optimize the value maximization of the economy. On the other hand, the agency problems arise between managers and owners since owners are typically assumed to be at an information disadvantage in monitoring managers. The latter with better firm-specific information are less likely to report detrimental information to their personal interests. The agency theory, formalized by Jensen and Meckling (1976) points out that the agency costs of deviation from value maximization increase as managers' stakes decrease and ownership becomes more disperse (Kwan, 2004).

In the following subsection, we focus on public and private banks, in which differences in the importance of asymmetry information and agency problems are substantial, resulting high heterogeneity on the shape banks’ risk profile.

\subsection{The opportunistic hypothesis}

Diffused ownership structure, commonly observed in public banks, can mitigate shareholders’ incentives to monitor managers’ actions. Diffused owners are more likely to adopt rational apathy. They remain passive when a sole owner monitors management (Black, 1992). Owing to the collective action problem, diffused shareholders bear the full costs of monitoring (e.g., the costs of storing, retrieving, and processing information) whereas they derive a limited share of gains from monitoring. Therefore, shareholders in public banks are more likely to use simple low-cost heuristics to assess and monitor bank risk (Burgstahler and Dichev, 1997, Beatty, Ke, and Petroni, 2002). In contrast, private shareholders have lower marginal costs of retrieving information, and reap a higher fraction of the benefits, suggesting that they are more likely to use fairly rich information, then closely monitor bank's management. It suggests that public banks may have higher risk taking incentives, then consequently are riskier than private banks.

Second, pressures from capital markets may have potential countervailing effects on incentives to report high-quality earnings. The reliance of investors on accounting information to evaluate short-term performance motivates public bank managers to take risky and myopia investments to build credibility from markets, to increase stock performance, or to boost their wages (e.g. Narayanan, 1985). Private bank managers do not face the same pressures from the market since they rely primarily on loans from banks and/or private lenders. As a result, private banks likely have weaker incentives to take "quick-profit” oriented investments, then less risky than public banks. 
A third reason for higher risk in public banks is related to the bonus hypothesis (Healy, 1985; Bergstresser and Philippon, 2006). Since the personal wealth of public banks' managers is positively correlated with stock valuation as a result of their stock ownership or stock-based compensation, these managers are more likely than managers of private banks to engage in risky investments. Cheng, Hong, and Scheinkman (2015) point out that bank managers with high compensations do not only take higher risks, but also more tail risk during the crisis.

Finally, shareholders in public banks are more diversified and will push for higher risk taking in exchange for higher expected returns. Moreover, because public banks have easier access to capital markets to finance their growth opportunities, they have more incentives to take risk.

According to these arguments, we posit our first hypothesis:

Opportunistic hypothesis (H1a): Public banks are riskier than private banks.

\subsection{The monitoring hypothesis}

The literature also suggests the countering mechanism from the capital market and the managerial labor market that mitigate the opportunistic behaviors arising from the separation of control and ownership (Bliss, 2001).

Under the efficiency hypothesis, the signals from the markets would allow the risksensitive security holders to accurately assess bank risk properties. The securities prices would correctly incorporate full and qualitative information related to bank underlying economics and then reflects the fair yield for risks. In the absence of any friction from governments or markets, securities holders can force banks back toward the adequate level of risks they would choose, lowering the potential agency problems and risk taking of banks. ${ }^{2}$ Otherwise, these securities holders may limit or withdraw their investments in the bank with the counterparty risk deemed unacceptable by the markets.

Another aspect of market discipline is the market influence which is the process by which the change of a security price encounters the responses from regulators. Even though depositors

\footnotetext{
${ }^{2}$ However, it requires securities holders consider themselves at risk of a bank becoming insolvent. The unprecedented number of supports from government in a plethora of countries following the last financial crisis renews and heightens concerns about moral hazard arising from investors' expectations of the government guarantees. That is, the government is believed to extend far beyond the de-jure boundaries of insured depositors, and de-facto protect other banks liability holders. A bulk of failing bank bailouts and the resulting protection of uninsured claimants from bearing the full losses reinforce this market perception (See e.g. Gandhi and Lustig, 2015). We will partially address this problem in the next section.
} 
of public and private banks are insured alike, and explicit regulatory reporting and capital requirements are the same for public and private banks (Beatty, Ke, and Petroni, 2002), however, being listed facilitates the regulators for controlling banks since information of public banks is upto-date, and more readily, leading to a faster reaction of regulators.

Public banks benefit greater access to capital markets at a lower cost than private banks do. Although one may argue that public banks may be riskier than private banks if the purpose to access capital market of the formers is to finance faster growth opportunities (Barry, Lepetit, and Tarazi, 2011), we posit that the banks with superior access to capital markets have higher franchise value - the present value of the stream of profits that a bank is expected to earn as a going concern, leading to a reduce of excessive risk taking since they have much to lose (Demsetz, Saidenberg, and Strahan, 1996).

Being listed also means that public banks are more likely to be covered by the information intermediaries like financial analysts and rating agencies which are deemed as the external monitors of management (Jensen and Meckling, 1976). With their substantial industry background knowledge, their interaction with management, these intermediaries engage in producing private information related to management. They can express their concerns related to covered banks through different channels such as research reports, recommendations, ratings, etc. (Yu (2008). These characteristics may mitigate the risk-taking behaviors of public banks.

Additionally, there is a greater separation between owners and managers in a typical public bank than a typical private bank (Nichols, Wahlen, and Wieland (2009). In contrast with shareholders who are usually well diversified, managers with non-diversifiable human capital are more likely to be conservative in risk taking to secure their human capital, protect their reputation and avoid losing their job. Consequently, these managers tend to orient to less volatile cash flow projects, leading to a lesser volatility of earnings, then bank’ risk.

According to these arguments, we posit our second hypothesis:

Monitoring hypothesis (H1b): Public banks are less risky than private banks.

\subsection{Related research}

To date, empirical findings provide limited evidence on the risk taking of public versus private banks. With their European bank sample, Barry, Lepetit, and Tarazi (2011) document ownership structure is associated with risk differences in private banks. But for public banks, changes in 
ownership structure do not affect risk taking. The authors conclude that market forces seem to align the risk-taking behavior of public banks, such that ownership structure is no longer a determinant in explaining risk differences. Recently, using an international bank sample, Samet, Boubakri, and Boubaker (2018)also documents a lower risk taking behavior in public banks versus their private peers. Kwan (2004) using US BHC sample, provides a mixed evidence. The author finds that public banks hold more capital than private banks whereas loan quality and earnings variability are comparable across public and private banks. However, the author only performs the bivariate analysis, hence its findings may be biased by other (observable and unobservable) bank characteristics.

In a related strand of literature, Beatty, Ke, and Petroni (2002) show that US public banks are more likely than private banks to manipulate earnings to avoid small earnings declines. Recently, Tran, Hassan, and Houston (2018) also documents a greater earnings management of US public banks versus their private peers which is partially explained by the pressure of capital requirements. Since banks become more opaque when manipulating their reported numbers, it interferes with private governance and official regulation of banks (Jiang, Levine, and Lin (2016)), leading higher opportunities for expropriation, and higher insolvency risks (Fosu et al. (2017).

\section{Data, and variables}

\subsection{Sample banks}

The Federal Reserve provides quarterly Y-9C regulatory reports filled by bank holding companies (BHC) with assets of \$150 million and over. Our raw data cover the period 2001:Q1 to 2015:Q4. We next remove any bank-quarters observations with missing or incomplete financial data on basis accounting variables of the main model of regression. Following Berger and Bouwman (2013), we replace all observations with the ratio of total equity over total assets less than by $1 \%$ to avoid distortion in ratios that contain equity, and also exclude observations with negative or no outstanding loans or deposits. Our data set has 43,814 observations for 2,314 BHCs. All financial ratios are winsorized at $1 \%$ level on the top and bottom of their distribution to dampen the effects of outliers. 


\subsection{Variables}

Following prior literature (See e.g. Laeven and Levine (2009), Berger et al. (2016), our primary measure of bank risk-taking behavior is ZSCORE which equals to the sum of return on assets and capital asset ratio over standard deviation of return on assets.. Banks with high ZSCORE are more stable than banks with low ZSCORE. The advantage of using ZSCORE is the reflection of both capital level and expected earnings of banks. When banks engage in new lines of business which are riskier, ZSCORE is not penalized if banks hold higher capital, or if the expected returns from new lines of business more than offset the greater risks (Wall (1987)).

In order to mitigate a potential omitted variable bias, we control for various bank-specific variables, as well as time (quarters) fixed effects. We include banks size (SIZE), capital ratio (CAPITAL), banks performance (DUMMY LOSS, and EARNINGS), assets growth (GROWTH), and functional diversification (NONINTEREST INCOMES). See Table 1 for definitions.

Table 2 reports the summary descriptive of these variables, and univariate tests between public and private banks. On average, public banks are larger, hold higher capital, and are more profitable than private banks. Furthermore, they have more growth opportunities, greater loans ratio and higher fraction of noninterest incomes in their revenue stream. Private banks rely more on deposits than public banks.

We plot the evolution of ZSCORE by listing status over the studied period. In general, we observe that public banks exhibit higher ZSCORE than private banks, except for the period of the financial crisis when public banks become riskier than their private peers.

\section{Does listing status affect bank risk?}

\subsection{Main findings}

Although univariate tests provide evidence of the dependence of listing status and bank risk, these tests omit a number of factors that could have impacts with both bank risk and listing status. Thus, in this section, we conduct multivariate analysis to formally investigate the magnitude of being listed on bank risk after controlling other control variables. Specifically, the empirical specification we estimate is as follows::

$$
Y_{i t}=\alpha+P U B L I C_{i t}+Z_{i t}+\theta_{t}+\varepsilon_{i t}
$$


where $Y_{i t}$ is the measure of ZSCORE of bank $i$ at time $t$. Our variable of interest is PUBLIC, which takes a value of 1 if bank $i$ is listed at quarter $t$, and 0 otherwise. $Z_{i t}$ is the vector of control variables described above. We include time-fixed effects, $\theta_{t}$, to control for time effects which can affect the risk profile of banks. $\varepsilon_{i t}$ is the error term. Since ZSCORE is likely to be correlated within a bank over time, standard errors used to assess significance are corrected for heteroscedasticity and banklevel clustering.

Our main results from the multivariate analysis are shown in Table 3, Panel A. We first include only PUBLIC and time fixed-effects in Model (1). The estimated constant indicates that the average ZSCORE of private banks is 46.541 , which is far from default. The coefficient on PUBLIC is positive and highly significant, suggesting that public banks are further from default than private banks.

Banks may fundamentally differ in their risk profile depending on different characteristics such as size, earnings, etc. If PUBLIC is correlated with any of these factors, the coefficient observed on PUBLIC in Model (1) may be biased. We add the control variables in Model (2). Again, the coefficient on listing status (PUBLIC) is positive, and statistically significant. The result indicates that ZSCORE of public banks are on average 7.680 higher than ZSCORE of private banks, with other independent variables held at their means. Based on the average ZSCORE of private banks of 42.060, this coefficient is economically important since it implies that ZSCORE is about $18.3 \%$ higher for public banks, compared to private banks. This indicates public banks are further from default than private banks, suggesting that the discipline forces from the markets dominate the agency problems of the greater separation of control, consistent with our Monitoring Hypothesis. These findings are in line with the evidence of Samet, Boubakri, and Boubaker (2018)with their international evidence.

In Model (3), we re-perform our baseline model with lag 12 of all explanatory variables following Berger et al. (2016) since our ZSCORE is computed over 12 quarters. Although we include control variables identified in literature in our baseline model, there may exist some omitted and correlated variables. In Models (4), we extend our baseline model by controlling for the effect of credit risk as measured by the ratio of non-performing loans (NPL), the structure of funding of banks as measured by the ratio of deposits over assets (DEPOSITS), and the volatility of earnings ( $\sigma($ EARNINGS)) . Again, we observe in all models that public banks experience higher ZSCORE than private banks. 
In Model (5), we re-perform the baseline model with the single cross-section regression (average analysis) to deal with the potential error-dependence problem. By performing this timeseries mean regression (one observation by bank), we eliminate the problem of serially correlated errors. This estimation still keeps the heterogeneity across banks, but does not exploit the timeseries variation in the observations. We still obtain similar findings. Having established the interplay of listing status and bank's risk, we further investigated how the risk profile of public banks should behave were they a private bank. We first estimate Equation (1) using only private bank sample. We then apply each individual public bank characteristic to the resulting regression model. By doing so, we obtain the predicted ZSCORE for each public bank, and take the difference between each bank's actual ZSCORE and its predicted ZSCORE. It is worth noting that this approach allows the coefficients on bank characteristics to vary across samples of public and private banks, which is not the case when using the pooled regressions with the coefficients on bank characteristics remained similar across samples. It in turn makes our results less biased. Further, this measure of ZSCORE not only wipes out the monitoring forces from the capital markets but also predicts the ZSCORE of public banks as if these banks have similar degree of opportunistic incentives as their private peers. As reported in Panel B, the mean of difference in column (1) is 6.782 , and significantly different from zero at $1 \%$ level. The result indicates that public banks would become riskier if they were the same bank but private. Within the same spirit, we re-perform all these procedures but with different propensity-score matched samples, ${ }^{3}$ and again we obtain similar findings.

Regardless of the control variables, we observe that large and well-capitalized banks are safer than other banks. The evidence also shows that high profitable and high growth banks experience higher ZSCORE than other banks. Banks with high fraction of loans, and of noninterest incomes are riskier than other banks. Additionally, banks experiencing loss have lower ZSCORE than other banks.

In brief, our findings reject the opportunistic hypothesis that the agency problems derived from the separation of ownership and control would make public banks become riskier than their private peers, and support the monitoring hypothesis that the pressure from capital markets and other external agents would lead public banks less risky. The results could be considered as the net effect of the reduced agency problems and the increased monitoring from external agents.

\footnotetext{
${ }^{3}$ We detail the propensity-score matching methods in the Section 5.
} 


\subsection{Alternative measures of risks}

In Table 4, Panel A, we re-conduct our baseline model with alternative measures of bank risks. In Models (1)-(2), we compute ZSCORE with different time horizons (over 8 and 16 quarters, respectively). In Model (3), following Foos, Norden, and Weber (2010), we compute abnormal ZSCORE which is the deviation of ZSCORE of bank $i$ at time $t$ with the average ZSCORE of the industry at time $t$. In all specifications, our main findings are unchanged.

We next use the non-performing loans ratio as proxy of bank risks. Loans are the largest earning assets of banks, and a higher ratio of non-performing loans reflects the bad quality of loan portfolio and the greater risk-taking behaviors of banks. The results reported in Model (4) indicate that there is no difference on the quality of loan portfolio between public and private banks after controlling other bank characteristics.

We then use the Tier 1 ratio (Tier 1 capital divided by risk-based assets) as proxy of bank risks in Model (5), and obtain a positive and statistically significant coefficient of PUBLIC, indicating that public banks have greater cushion of regulatory capital to absorb losses than private banks. Some may argue that Tier 1 ratio is subject to manipulation since the risk-weight calculation is left to the discretion of bank managers (Mariathasan and Merrouche (2014). In an unreported test, we use the Tier 1 leverage ratio (Tier 1 capital divided by total assets), and we still find similar findings.

In Model (6), we use the cost of deposits as proxy of bank risks. As the solvency risk of a bank increases, it might reflect through a higher rates offered to depositors to attract more deposits. Then, the heathier banks are, the lower costs they pay. The results document that public banks pay less than private banks, indicating that public banks are less risky than their private peers.

\subsection{Alternative samples}

In Table 4, Panel B, we re-conduct our baseline model with alternative samples. We focus on scale-effect since public banks are usually larger than private banks. It is widely accepted in the literature that larger money centers or regional banks have different product mix and funding sources than small community banks (Kwan, 2004). Large banks are less focused on traditional bank lending and they also face tighter prudential supervision and regulatory constraints given their systemic importance within banking sector. To alleviate the concern that a few large banks are influencing our results, we exclude top $10^{\text {th }}$ largest banks in Model (1). In Model (2), we 
exclude too-big-to-fail entities, defined as banks with assets greater than $\$ 100 \mathrm{~B}$, consistent with banks that were subject to stress tests or the Supervisory Capital Assessment Program (SCAP) and the first Comprehensive Capital Analysis and Review (CCAR). We continue to find that private banks are riskier than public banks, suggesting that our main result is not driven by too-big-to-fail or the largest banks.

Next, we report results by bank size to investigate whether our core finding is concentrated in a particular bank size class. In Models (3)-(5), we find that listing status is associated with less risk across all size classes. ${ }^{4}$

\subsection{Alternative estimation methods}

In this section, we perform Equation (1) with alternative estimation methods. Even the investigations in Panel B are for the concerns related to the effects of bank size, to ensure that our core result is not driven by bank size, we use weighted OLS regressions where the weight is the bank’s inverse total assets. Again, we obtain public banks is less risky than private banks.

In Models (2)-(4), we perform quantile regressions - a generalization of median regression analysis to other quantiles - to assess whether the interplay between listing status and risk differ across the quantile of risk. The traditional inference approach (i.e. the ordinary least squares, OLS) used in above sections describes the average behavior of the sample with the assumption of the homogenous of the effects of ownership structure on bank risks. However, when the heterogeneity in the sample is important, there may be a poor description from this traditional approach. Rather than relying on a single description of the central behavior of the sample, the quantile approach explores a range of conditional quantile functions, which in turn allows us to explore potential forms of conditional heterogeneity.

Indeed, the results above show the conditional mean effects of listing status on bank risk. One may suspect that the mean differences between public and private banks are driven by the top quantile of the risk distribution. The Figures (1B)-(1E) confirm this concern. The coefficients on

\footnotetext{
${ }^{4}$ We also check for the nonlinear relationship between risk and size by including size-decile fixed effects to control for unobserved heterogeneity across banks in different size categories as suggested in Ellul and Yerramilli (2013). We obtain similar results. Additionally, since size is, to a large extent, an outcome of bank decision making, then is highly correlated with other independent and dependent variables, we decompose bank size with respect to all other independent variables into two components: an organic growth component that is measured by the fitted value, and a historical size component that equals to residual. Orthogonalizing size allows us to derive the pure effects of size (De Jonghe, 2010). The result is unchanged.
} 
PUBLIC in Models (2)-(4) show that the impacts of listing status on bank risk are indeed uniform in sign (positive), but increased significantly in magnitude with the increase of quantiles. In an unreported test, we perform inter-quantile regressions (i.e. regressions of difference-in-quantiles) to assess whether these differences of coefficients on PUBLIC across quantiles are significant. For example, the difference in coefficients of two quantile (Q75 - Q25) regressions is 8.912, statistically significant at the $1 \%$ level. ${ }^{5}$ Overall, our empirical findings indicate that listing status does not only affect the conditional average ZSCORE, but also influences the ZSCORE dispersion. More concretely, the effect of listing status is lower in conditional high-risk bank as documented in Figure (2) where we plot the estimated effect of the listing status from night separate quantile regressions for the quantiles ranging from 0.10 to 0.90 .

In Models (5)-(8), we also perform Newey-West, Prais-Winsten Fama-MacBeth and twoway clusters procedures. In all specifications, our findings remain unchanged.

\section{Is the choice of being public endogenous?}

The specification in Equation (1) is based on the assumption that a bank's decision to go public is exogenous. However, research shows that listing status is endogenous and is a deliberate decision by bank managers. Our results may be derived from the unobservable differences between public and private banks that simultaneously affect the decision to go public/stay private and the earnings management behavior of banks. These unobservable differences could lead to potential bias in the OLS framework. Thus, we complement our OLS estimation with different matching procedures, the Heckman selection model and the instrumental variable approach. These procedures should control for any selection bias that may be present in the above estimation. The results are tabulated in Table 5.

\subsection{Propensity score matching}

We first employ the propensity score matching (PSM) system developed by Rosenbaum and Rubin (1983) and extended by Heckman, Ichimura, and Todd (1997).

To conduct propensity score matching (PSM), we separate the full sample into two groups: public (treated) and private (untreated) banks. Next, we measure the propensity of undergoing treatment (i.e. the probability of going public) by using a logit model for both treated and untreated

\footnotetext{
${ }^{5}$ We use the bootstrapping methods (100 replications) to obtain the variance-covariance matrix of the estimators.
} 
samples. Our dependent variable in this logit model is a binary variable which equals 1 if the bank goes public, and equals zero otherwise. ${ }^{6}$ Then, we match each public bank with one or more private banks sharing similar characteristics as reflected in their propensity scores. ${ }^{7}$ We initially use one-to-one matching without replacement, which requires each private bank to be used exactly one time. We also use one-to-one matching with replacement, which allows each private bank to be used more than once. We also match each public bank with the two and three private banks with the closest propensity scores. ${ }^{8}$ We present the results of our PSM analysis in Models (1)-(4), Table 5. The results are robust to different specifications of PSM. We observe that the magnitude of coefficients of listing status from PSM specifications is weaker than in our baseline model.

\subsection{Selection model for public versus private ownership}

The matching estimators presented above mitigate the selection bias. However, there may be unobservable factors that explain decisions to go public. We use the Heckman two-step approach to eliminate the bias due to unobservable variables. We first model the selection of public and private status by using the logit selection model, and then obtain the inverse Mills ratio (IMR) the omitted variable in Equation (1). The accounting literature (See, e.g., Ball and Shivakumar, 2005; Kim and Yi, 2006; Nichols, Wahlen, and Wieland, 2009) usually includes firm size, leverage, and growth in the logit listing-choice model as explanatory variables. Following Laeven and Levine (2007), we add the fraction of listed banks in the quarter with control variables defined in Equation (1). ${ }^{9}$ We then estimate the logit listing-choice model and calculate IMR. The IMR is the conditional expectation of the model selection error term, given the banks' observable characteristics and ownership status. In the second stage, we re-estimate Equation (1) by including IMR as an additional control variable to correct for potential self-selection biases. We also include the interaction term IMR*PUBLIC to allow the variation of IMR between public and private banks

\footnotetext{
${ }^{6}$ We detail the first-stage in Section 5.2.

${ }^{7}$ We retain only untreated observations whose propensity scores fall inside the interval defined for the treated group. We impose a tolerance level of $0.5 \%$ on the maximum propensity score distance allowed (caliper), to minimize the risk of bad matches.

${ }^{8}$ Using this oversampling matching leads to a trade-off between bias and variance. Since more information is used to construct the counterfactual for each participant, leading to a decreased variance, it increases bias resulting from poorer matches.

${ }^{9}$ We also test for several variations of the first-stage model following prior research. First, we use lagged value of explanatory variables since one may argue that a bank's choice to go public is based on its underlying economics of the past year (Kim and Yi, 2006). We also add the components of loan portfolio as in Nichols, Wahlen, and Wieland (2009). Inclusion or exclusion of these variables has no qualitative effect on our results.
} 
(Nichols, Wahlen, and Wieland, 2009).

Model (5) in Table 5 reports the maximum likelihood estimates of the logit listing-choice. All coefficients are highly significant. Large, well-capitalized and high-growth banks are more likely go public, whereas highly profitable banks and banks that encounter loss tend to be private. Model (6) reports the second-stage model results. Consistent with our core finding, public banks exhibit greater ZSCORE.

\subsection{Instrumental variables approach}

We conclude our inquiry into endogeneity of listing status with an instrumental variables (IV) estimation. This estimation extracts the exogenous component of the listing status of banks. The instrument is the fraction of listed banks as documented in the preceding section.

We report the first-stage and second-stage IV regression results in Models (7) and (8) of Table 5. In Model (7) our IV is positively and significantly associated with listing status. This confirms the relevance of our IV. The result of second-stage supports the hypothesis that public banks are safer than private banks. We observe that the coefficient of IV estimation is much larger in absolute value than the OLS estimate, which is consistent with our concern about the reverse causality and hence with the need to use IV to identify the impact of going public on bank risk. The OLS estimation might yield coefficient estimates of the impact of listing status on risk that are biased toward zero, whereas the IV estimation yields the more accurate (and larger) impact of listing status on bank risk profile. ${ }^{10}$

\subsection{The transitioning sample}

In this section, we examine the changes in bank riskiness for a sample of banks that undergo a change in ownership status: (i) from private bank to public bank (Going IPO); and (ii) from public bank to private bank (Going private). Using the transition set allows us to compare the same bank as both a private and public bank, mitigating the concern of invariant unobservable bank characteristics. It is worth noting that although this sort of examination is not a true endogeneity

\footnotetext{
${ }^{10}$ In an unreported test, we also perform the system GMM with instruments as lagged values to all independent variables except for time dummies that we suggest to be exogenous. We restrict the lag range to 3 in order to limit the number of instruments. We still obtain a positive and significant coefficient of PUBLIC. The Hansen (overidentification) test which is used to valid these instruments (Ho: All instruments are valid) indicates that we cannot reject the null hypothesis ( $\mathrm{p}$-value=0.653). We also perform the Arellano and Bond test for the absence of second order residual autocorrelation (AR2 test) (p-value=0.322). In other specification, we include the fraction of listed banks to the instrument variables, and still find similar finding.
} 
test, and deals with only a fraction of specific banks, it would allow us to investigate whether banks become more or less risky when they change their ownership status.

For transition sample from private to public status (public to private status), we identify 161 IPOs (41 going-private) during the period 2001:Q1-2015:Q4. We next measure their mean level of ZSCORE for a period of $4(8,12,16)$ quarters prior and $4(8,12,16)$ quarters following the transition date. Then we take the difference of ZSCORE. The results of going IPO samples are reported in Table 5, Panel B, and the results of going private samples are reported in Panel C.

For going IPO samples, with the window of 4 quarters (prior and after IPO date), there is no improvement of ZSCORE after IPO since the mean difference is statistically insignificant (Column (1)). However, the more we enlarge the window, the more we observe the positive change in ZSCORE of banks that go IPO. With a window of 8 quarters prior and following the IPO (Column (2)), transitioning banks significantly enhance their safety (i.e. increase ZSCORE). Similar findings are also found with 12- and 16-quarters window (Columns (3), (4) respectively).

For going private samples, we document significant decrease of ZSCORE of banks after going private. For example, for a window of 4-quarters prior and following the event date, the decrease of ZSCORE is 10.946, which means, a decrease of 38\% of ZSCORE to compare with the period before going private.

Since the average ZSCORE of private and public banks of the total sample is 42.060 and 51.408, respectively, we observe that private banks that go IPO is generally safer than other private banks, however, it seems that these banks perform in the lesser extent than other public banks. ${ }^{11}$ Similarly, the data from Panel C indicates that public banks that go private perform worsen than other private and public banks. This poor performance of these transition public banks may be the reason for a leave of the stock markets. This evidence of poor performance of public banks that go private also casts doubt the Jensen (1986)'s suggestion of going private in order to create an organizational form to control the agency problems.

In brief, the results from Panel B and C suggest a significant increase of ZSCORE when banks change their ownership structure from private to public, and a significant erode of ZSCORE when public banks become private.

\footnotetext{
${ }^{11}$ From Table 5, Panel B, we observe that the average ZSCORE of private banks before going IPO is around 47, and after going IPO is around 50 .
} 


\section{Bank risk and listing status: The effects of the crises, market discipline and regulatory pressures.}

\subsection{The effects of the crises}

We use the financial crises as a quasi-natural experiment to examine whether the difference in risk taking between public and private banks changes under the effects of crises. We identify the last crisis from 2007:Q3-2009-Q2 following Cornett et al. (2011).

One may argue that the discipline forces may be increased by the public's heightened awareness of bank risk. Listed banks also face monitoring pressure from the capital markets, leading to lower risk-taking behaviors of public banks during crises. However, public banks which are bigger, and more complex, become riskier during the crisis due to their organizational complexity, making it difficult for management to deal with the crises. Public banks may also rely on different funding sources such as wholesale funding, capital markets, etc... which become more volatile during crises, whereas private banks which are usually smaller community banks may rely more on more stable sources of funding (e.g. insured deposits). Additionally, literature also indicates that discipline forces may be decreased by the government interventions taken at the beginning of or during the crisis.

We first use the variation in ZSCORE and bank characteristics in a panel setting to assess whether ZSCORE of (private and public) banks in time of crisis differs from the pre-crisis period, taking into account the changes of bank characteristics. To do so, we start by splitting the panel into private and public bank sample, then perform Equation (1) for the pre-crisis period. We next use the estimated coefficients to predict ZSCORE of public and private banks during the crisis. By comparing these predicted ZSCORE with actual ZSCORE during the crisis, we document how the risk profile of each type of banks (private or public) during the crisis should be if they were in precrisis time. The results are shown in Table 6, Panel A.

We observe that in column (1), banks become riskier during crisis, since the difference are negative and statistically significant at the $1 \%$ level. In addition, ZSCORE of public banks decrease in a greater extent than private banks (-11.882 vs -1.748). In columns (2)-(5), we perform the same analyses, but with samples from PSM. We obtain similar findings, however, the relative gap between private and public banks decrease.

We continue the investigation of the effects of the crisis on the relation between listing 
status and bank risk. We re-perform Equation (1) by adding the interaction of the crisis dummy with PUBLIC (PUBLIC * CRISIS). The results are reported in Model (1), Table 6, Panel B. ${ }^{12}$ The coefficient of interaction term (PUBLIC*CRISIS) is negative and statistically significant, indicating that public banks become riskier during financial crises than private banks. This evidence suggests the risk-mitigating role of listing status is rule out, and it casts doubt on the effectiveness of the discipline forces exerted by the markets and regulators.

\subsection{Further investigations}

We then go further by assess how the market discipline and regulatory pressures can alter the interplay of listing status and bank risk during the financial crisis. The crisis is a unique occasion to assess market discipline. Banks become weaker during the crisis, they are more prone to runs and failures. To avoid losing their investments, investors are more likely to discipline banks during these periods, which may not be true during the normal times. Furthermore, traumatic periods may make investors more vigilant, increasing their awareness of the risk of their investments, and providing them with a "wake-up call” that strengthens market discipline (Martinez Peria and Schmukler, 2001). Acharya and Mora (2015) point out that at the onset of the financial crisis, banks were not indiscriminately seen as safe havens during this crisis. Subordinated debts are suggested as a tool of discipline for bank (Bliss, 2001, Bliss and Flannery, 2002). The anticipation of higher funding costs will send signal to bank to (ex-ante) refrain its further risk-taking behavior (Kwast et al., 1999). One may argue that if the market discipline is present, the discipline role of subordinated debt would be more pronounced with public banks since those banks rely on different sources of funding which become more volatile during the crisis. However, it requires securities holders consider themselves at risk of a bank becoming insolvent. The unprecedented number of supports from government in a plethora of countries following the last financial crisis renews and heightens concerns about moral hazard arising from investors' expectations of the government guarantees. That is, the government is believed to extend far beyond the de-jure boundaries of insured depositors, and de-facto protect other banks liability holders. A bulk of failing bank bailouts and the resulting protection of uninsured claimants from bearing the full losses reinforce this market perception. This anticipation of public guarantee benefits shareholders ex-ante (Gandhi

\footnotetext{
${ }^{12}$ We do not use crisis dummies as stand-alone since they are subsumed by the time fixed-effects. However, replacing time fixed-effects by crisis dummies do not change our results.
} 
and Lustig, 2015), and creates incentives for banks to become even larger and more complex, because investors may discount risks when supplying funds for potential candidates, and those banks may in turn borrow at an artificially risk-insensitive costs, implying an aggressive increase of risk-taking in pursuit of higher returns of not only protected banks, but also their competitors through competition (Hakenes and Schnabel, 2010). This may exacerbate the likelihood and severity of future crises. Since the effects of market discipline may be affected by the government interventions, we do not posit on any direction of those effects.

We suggest that during the crises, banks with high franchise value would be less risky than others, and this effect is more pronounced in public banks, since as argued in Section 2, public banks have more to lose in case of insolvent.

We also focus on the impact of bank regulatory pressure during the financial crisis on the interplay between listing status and risk. The regulatory constraints on banks aim at discouraging bank risk-taking, preventing bank failures, especially during the crisis. This effect would be more pronounced with listed banks due to their systematic characteristics as well as their more readily information. However, in the wake of the last financial crisis, regulators are heavily criticized for the inadequate amount of minimum capital required by their frameworks (Allen and Carletti, 2010). Furthermore, during a financial crisis when distress is systematic, regulatory forbearance is often applied to avoid disruptions from bank failures to the real economy and the financial system (Huizinga and Laeven, 2012). Consequently, banks are more likely to exert more discretion over accounting rules to understate balance sheet stresses (Acharya, Schnabl, and Suarez, 2013, Le Leslé and Avramova, 2012). Hence, we do not expect the expected sign of the regulatory pressure on the interplay between risk and listing status.

We use the core deposits (CORE DEPOSITS) as proxy of franchise value, the subordinated debts (SUBDEBT) as the proxies of investors discipline. Banks which have greater core deposits have more (deposit) franchise value (English, Van den Heuvel, and Zakrajsek, 2012), and those which rely more on subordinated debts face higher market discipline. For regulatory pressure, we use the dummy variable (REG) which equals to one if the Tier 1 ratio of banks belongs to the lowest quartile. ${ }^{13}$ We include these variables and their interactions with our variable of interest

\footnotetext{
${ }^{13}$ In an unreported test, we use difference proxies for regulatory pressures (e.g. we identify banks with the Tier 1 ratio under $8 \%$ or the Tier 1 leverage ratio under 7\% following Abreu and Gulamhussen (2013), or banks with Tier 1 ratio under 6\% following Onali (2014). We obtain similar findings.
} 
(PUBLIC), and re-perform Equation (1). The results are tabulated in Models (2)-(4).

Model (2) assesses the impacts of franchise value on the interplay between listing status and bank risk. As expected, the interaction term (PUBLIC * CORE DEPOSITS * CRISIS) is positive and statistically significant at the $1 \%$ level, indicating that during the crisis, public banks with high franchise value will lower their risk-profile. Interestingly, this mitigating role of deposit franchise value appears only during the crisis, since we do not observe any relation during the normal times (the interaction term PUBLIC * CORE DEPOSITS is statistically insignificant).

Turning to the effects of market discipline from subordinated debt investors, the interaction term (PUBLIC * SUBDEBT * CRISIS) is negative but statistically insignificant, indicating that subordinated debt investors do not play any role to constrain listed banks' risk taking. Similar finding is found during the normal times (the interaction term PUBLIC * SUBDEBT is not statistically significant). This evidence is consistent with Bliss and Flannery (2002) who find little evidence that stock or bond investors influence managerial actions, casting doubt on the effectiveness of the market in shaping managers' behavior. Recently, Acharya, Anginer, and Warburton (2016) suggest that debtholders discipline is less effective in curbing the risk-taking behavior of banks.

Regarding to the effectiveness of the regulatory pressure, the interaction term (PUBLIC * REG * CRISIS) is negative and statistically significant, suggesting public banks subject to high regulatory pressure are riskier during the crisis. The interaction term (PUBLIC * REG) is however positive and statistically significant, meaning that public banks subject to high regulatory pressure are less risky during the normal times. These findings cast doubt the effectiveness of regulators during the last crisis.

\section{Conclusions}

In this study, we provide one of the first large-sample comparisons of risk-taking in public and private US banks. We exploit a dataset which allows us to examine the impact of variations in information asymmetry. Our finding shows that public banks are less risky than private banks,

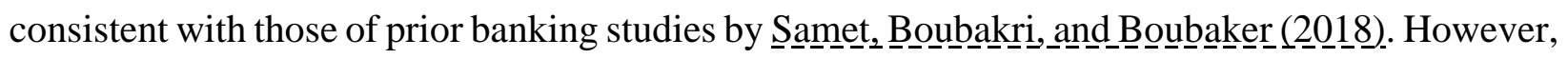
during the crisis, public banks become riskier, casting doubt the effectiveness of the risk-taking mitigating role of listing status during this turmoil times. We provide a battery of sensitivity tests to ensure the robustness of our findings. Deposit franchise value is effective to limit risk taking in 
public banks during the crisis, but not during the normal times. In contrast, we document an interesting fact that regulatory pressure is effective in limiting risk taking by undercapitalized public banks before, but not during the crisis. The discipline forces from the subordinated debt holders are inefficiency in curbing the risk-taking behavior of banks. We believe that our results are of interest of regulators and policymakers.

\section{References}

Abreu, José Filipe, and Mohamed Azzim Gulamhussen, 2013, Dividend payouts: Evidence from U.S. bank holding companies in the context of the financial crisis, Journal of Corporate Finance 22, 54-65.

Acharya, Viral V., Deniz Anginer, and A. Joseph Warburton, 2016, The End of Market Discipline? Investor Expectations of Implicit Government Guarantees. SSRN Scholarly Paper, Social Science Research Network, Rochester, NY.

Acharya, Viral V., and Nada Mora, 2015, A Crisis of Banks as Liquidity Providers, The Journal of Finance 70, 1-43.

Acharya, Viral V., Philipp Schnabl, and Gustavo Suarez, 2013, Securitization without risk transfer, Journal of Financial Economics 107, 515-536.

Allen, Franklin, and Elena Carletti, 2010, An Overview of the Crisis: Causes, Consequences, and Solutions*, International Review of Finance 10, 1-26.

Armstrong, Christopher S., Wayne R. Guay, and Joseph P. Weber, 2010, The role of information and financial reporting in corporate governance and debt contracting, Journal of Accounting and Economics 50, 179-234.

Ball, Ray, and Lakshmanan Shivakumar, 2005, Earnings quality in UK private firms: comparative loss recognition timeliness, Journal of Accounting and Economics 39, 83-128.

Barry, Thierno Amadou, Laetitia Lepetit, and Amine Tarazi, 2011, Ownership structure and risk in publicly held and privately owned banks, Journal of Banking \& Finance 35, 1327-1340.

Beatty, Anne, and David G. Harris, 1999, The Effects of Taxes, Agency Costs and Information Asymmetry on Earnings Management: A Comparison of Public and Private Firms, Review of Accounting Studies 4, 299-326.

Beatty, Anne L., Bin Ke, and Kathy R. Petroni, 2002, Earnings Management to Avoid Earnings Declines across Publicly and Privately Held Banks, Accounting Review 77, 547-570.

Berger, Allen N., and Christa H. S. Bouwman, 2013, How does capital affect bank performance during financial crises?, Journal of Financial Economics 109, 146-176. 
Berger, Allen N., Sadok El Ghoul, Omrane Guedhami, and Raluca A. Roman, 2016, Internationalization and Bank Risk, Management Science 63, 2283-2301.

Bergstresser, Daniel, and Thomas Philippon, 2006, CEO incentives and earnings management, Journal of financial economics 80, 511-529.

Black, Bernard S., 1992, Institutional investors and corporate governance: The case for institutional voice, Journal of applied corporate finance 5, 19-32.

Bliss, Robert R., 2001, Market discipline and subordinated debt: A review of some salient issues, Economic Perspectives-Federal Reserve Bank of Chicago 25, 24-45.

Bliss, Robert R., and Mark J. Flannery, 2002, Market Discipline in the Governance of U.S. Bank Holding Companies: Monitoring vs. Influencing, Review of Finance 6, 361-396.

Burgstahler, David, and Ilia Dichev, 1997, Earnings management to avoid earnings decreases and losses, Journal of Accounting and Economics 24. Properties of Accounting Earnings, 99-126.

Cheng, Ing-Haw, Harrison Hong, and José A. Scheinkman, 2015, Yesterday's Heroes: Compensation and Risk at Financial Firms, The Journal of Finance 70, 839-879.

Cornett, Marcia Millon, Jamie John McNutt, Philip E. Strahan, and Hassan Tehranian, 2011, Liquidity risk management and credit supply in the financial crisis, Journal of Financial Economics 101, 297-312.

De Jonghe, Olivier, 2010, Back to the basics in banking? A micro-analysis of banking system stability, Journal of Financial Intermediation 19. Risk Transfer Mechanisms and Financial Stability, 387-417.

Demsetz, Rebecca S., Marc R. Saidenberg, and Philip E. Strahan, 1996, Banks with Something to Lose: The Disciplinary Role of Franchise Value. SSRN Scholarly Paper, Social Science Research Network, Rochester, NY.

Ellul, Andrew, and Vijay Yerramilli, 2013, Stronger Risk Controls, Lower Risk: Evidence from U.S. Bank Holding Companies, The Journal of Finance 68, 1757-1803.

English, William B., Skander Van den Heuvel, and Egon Zakrajsek, 2012, Interest Rate Risk and Bank Equity Valuations. SSRN Scholarly Paper, Social Science Research Network, Rochester, NY.

Foos, Daniel, Lars Norden, and Martin Weber, 2010, Loan growth and riskiness of banks, Journal of Banking \& Finance 34. International Financial Integration, 2929-2940.

Fosu, Samuel, Collins G. Ntim, William Coffie, and Victor Murinde, 2017, Bank opacity and risktaking: Evidence from analysts' forecasts, Journal of Financial Stability 33, 81-95.

Gandhi, Priyank, and Hanno Lustig, 2015, Size Anomalies in U.S. Bank Stock Returns, The Journal of Finance 70, 733-768. 
Hakenes, Hendrik, and Isabel Schnabel, 2010, Banks without parachutes: Competitive effects of government bail-out policies, Journal of Financial Stability 6, 156-168.

Healy, Paul M., 1985, The effect of bonus schemes on accounting decisions, Journal of Accounting and Economics 7, 85-107.

Heckman, James J., Hidehiko Ichimura, and Petra E. Todd, 1997, Matching as an econometric evaluation estimator: Evidence from evaluating a job training programme, The review of economic studies 64, 605-654.

Huizinga, Harry, and Luc Laeven, 2012, Bank valuation and accounting discretion during a financial crisis, Journal of Financial Economics 106, 614-634.

Jensen, Michael C., and William H. Meckling, 1976, Theory of the firm: Managerial behavior, agency costs and ownership structure, Journal of Financial Economics 3, 305-360.

Jiang, Liangliang, Ross Levine, and Chen Lin, 2016, Competition and bank opacity, Review of Financial Studies 29, 1911-1942.

Kim, Jeong-Bon, and Cheong H. Yi, 2006, Ownership Structure, Business Group Affiliation, Listing Status, and Earnings Management: Evidence from Korea*, Contemporary Accounting Research 23, 427-464.

Kwan, Simon H., 2004, Risk and Return of Publicly Held Versus Privately Owned Banks. SSRN Scholarly Paper, Social Science Research Network, Rochester, NY.

Kwan, Simon H., 2004, Risk and return of publicly held versus privately owned banks, .

Kwast, Myron L., Daniel Covitz, Diana Hancock, James Houpt, David Adkins, Norah Barger, Barbary Bouchard, John Connolly, Thomas Brady, William English, and others, 1999, Using subordinated debt as an instrument of market discipline, Report of a Study Group on Subordinated Notes and Debentures, M. Kwast, Chair. Board of Governors of the Federal Reserve System, Staff Study 172.

Laeven, Luc, and Ross Levine, 2007, Is there a diversification discount in financial conglomerates?, Journal of Financial Economics 85, 331-367.

Laeven, Luc, and Ross Levine, 2009, Bank governance, regulation and risk taking, Journal of financial economics 93, 259-275.

Le Leslé, Vanessa, and Sofiya Yurievna Avramova, 2012, Revisiting risk-weighted assets, .

Martinez Peria, Maria Soledad, and Sergio L. Schmukler, 2001, Do depositors punish banks for bad behavior? Market discipline, deposit insurance, and banking crises, The Journal of Finance 56, 1029-1051.

Narayanan, M. P., 1985, Managerial Incentives for Short-term Results, The Journal of Finance 40, 1469-1484. 
Nichols, D. Craig, James M. Wahlen, and Matthew M. Wieland, 2009, Publicly traded versus privately held: implications for conditional conservatism in bank accounting, Review of Accounting Studies 14, 88-122.

Onali, Enrico, 2014, Moral Hazard, Dividends, and Risk in Banks, Journal of Business Finance \& Accounting 41, 128-155.

Rosenbaum, Paul R., and Donald B. Rubin, 1983, The central role of the propensity score in observational studies for causal effects, Biometrika 70, 41-55.

Samet, Anis, Narjess Boubakri, and Sabri Boubaker, 2017, Does public-private status affect bank risk taking? Worldwide evidence, Journal of International Financial Markets, Institutions and Money.

Tran, Dung V., Kabir M. Hassan, and Reza Houston, 2018, Discretioanry loan-loss provision behavior in the US banking industry.

Wall, Larry D., 1987, Has bank holding companies' diversification affected their risk of failure?, Journal of Economics and Business 39, 313-326.

Yu, Fang (Frank), 2008, Analyst coverage and earnings management, Journal of Financial Economics 88, 245-271. 
Figure 1. Evolution of ZSCORE by Listing Status over Time

(1A)

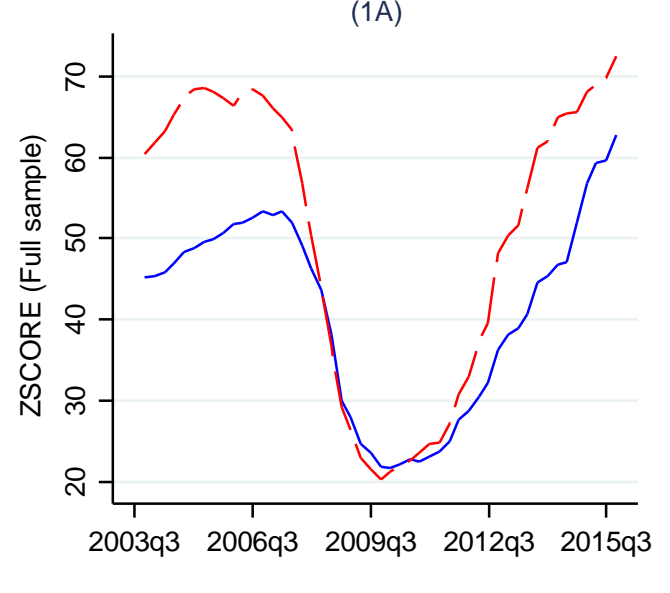

Private

(1D)

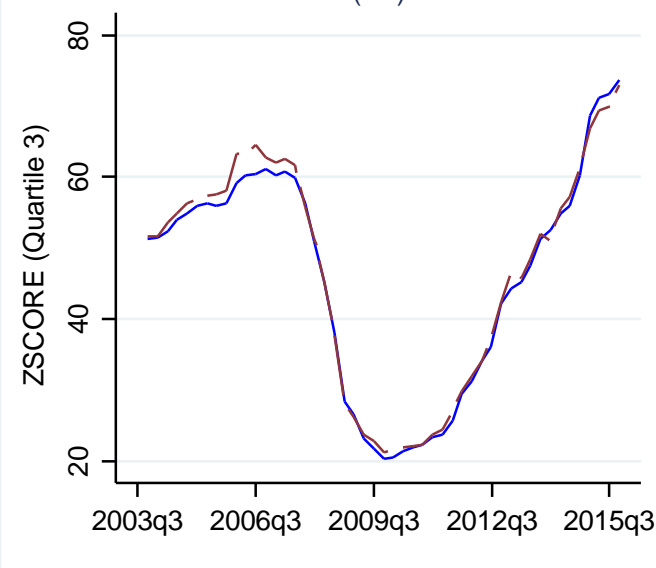

(1B)

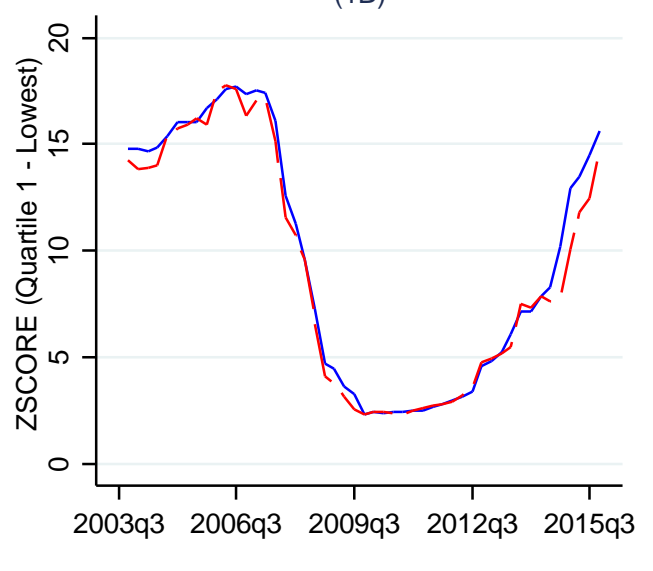

Private

(1E)

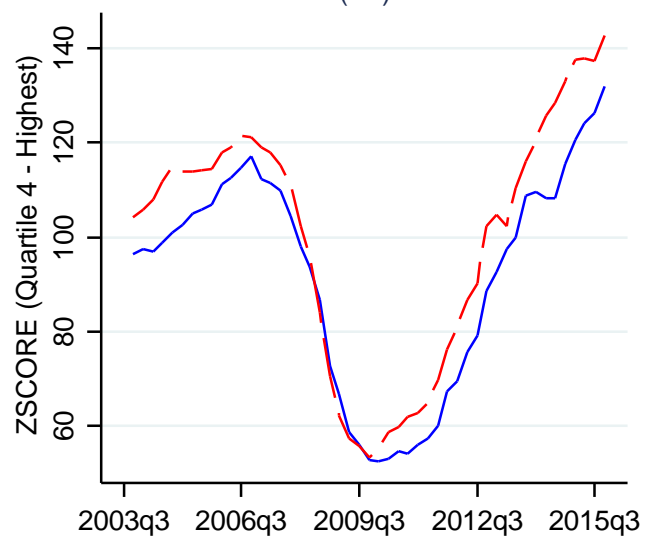

Private

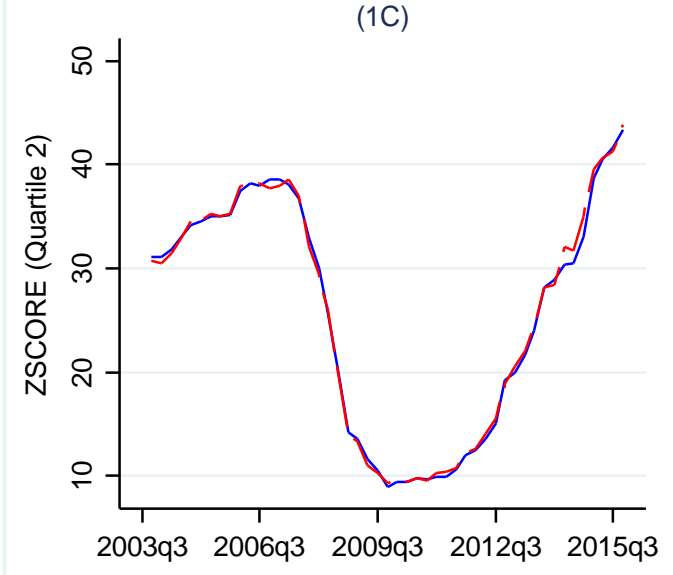

Private 


\section{Figure 2. Bank Risk and Listing Status - Quantile Estimates}

$\mathrm{Y}$-axis is the listing status. X-axis is the quantile of ZSCCORE. The blue horizontal dashed line is the (constant) OLS estimate. The red connected line in the shaded (confidence level) region are the separate quantile regression estimates.

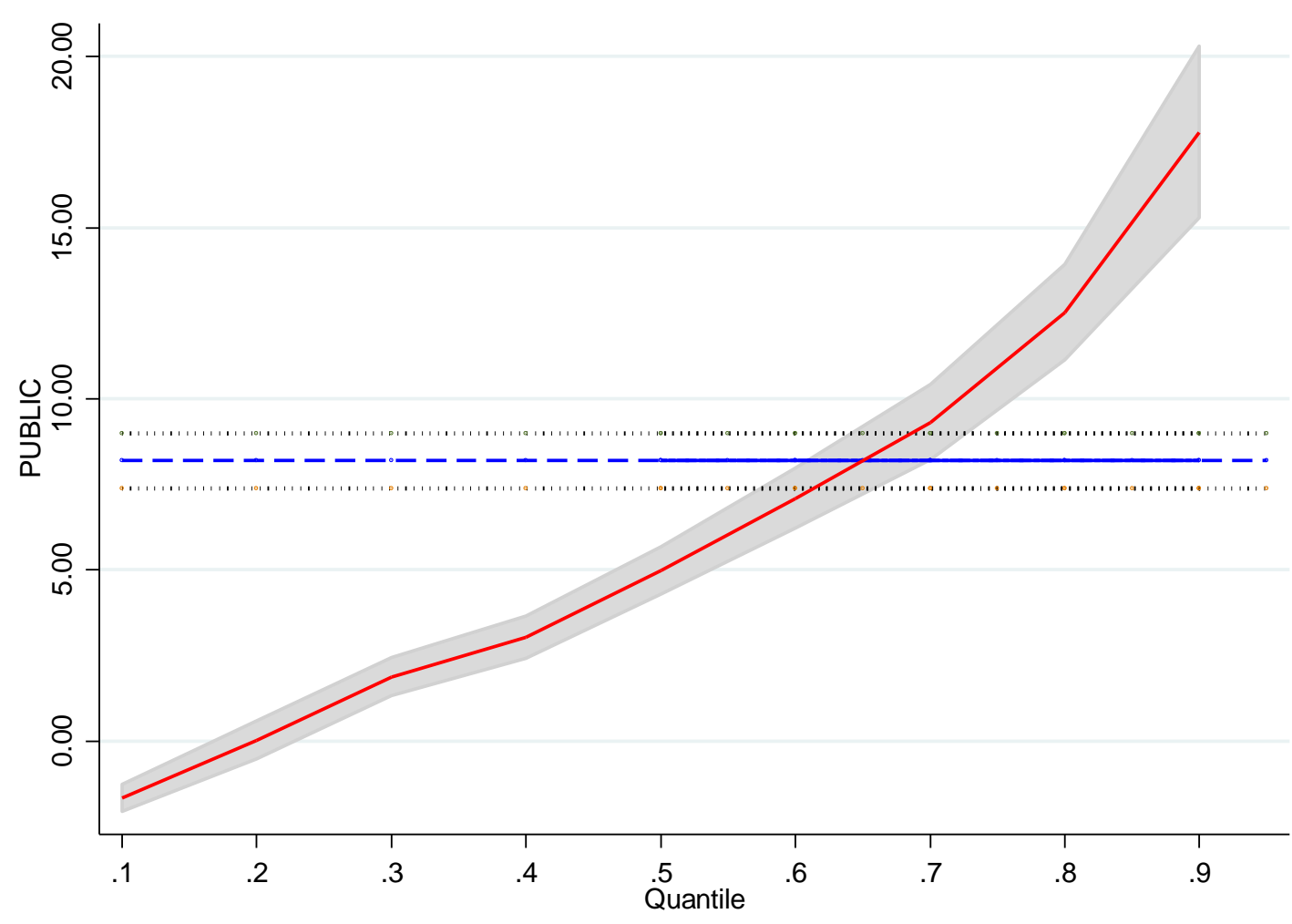




\section{Table 1. Variables Definitions}

This table presents definitions of all main variables used in the analysis.

\begin{tabular}{|l|l|}
\hline Variables & Definitions \\
\hline ZSCORE & $\begin{array}{l}\text { A bank measure of financial risk calculated as } \frac{\mathrm{CAP}+\mu_{\mathrm{ROA}}}{\sigma_{\mathrm{ROA}}} \text {; a larger value indicates lower } \\
\text { overall bank risk; means of ROA and Equity/GTA as well as the standard deviation of } \\
\text { ROA are computed over the previous 12 (or 8, 16) quarters }\end{array}$ \\
\hline ABNORMAL ZSCORE & The deviation of ZSCORE of bank i at time t from the average of the industry at time t \\
\hline PUBLIC & A dummy that takes a value of 1 if the bank is listed on a stock exchange, 0 otherwise. \\
\hline SIZE & The natural logarithm of gross total assets \\
\hline CAPITAL & Book value of equity over gross total assets \\
\hline DUMMY LOSS & A dummy variable that equals one if net income is negative, and zero otherwise \\
\hline EARNINGS & Income before taxes, provisions recognized in income over gross total assets \\
\hline LOAN & Loans / Gross total assets \\
\hline NONINTEREST INCOMES & Noninterest income / Net operating income \\
\hline CRISIS & $\begin{array}{l}\text { A dummy equal to } 1 \text { for a financial crisis period, and 0 otherwise., following Berger and } \\
\text { Bouwman (2013) }\end{array}$ \\
\hline CORE DEPOSITS & Core deposits / Gross total assets (See Acharya and Mora, 2015) \\
\hline SUBDEBT & Subordinated notes and debentures / Gross total assets \\
\hline REG & A dummy variable equals to one if the Tier 1 ratio of banks is belong to the lowest quartile \\
\hline QFE & Time fixed effects, represented by dummies for each quarter of the sample period. \\
\hline
\end{tabular}


Table 2. Summary Statistics and Univariate Tests

This table reports summary statistics for the main sample of U.S. commercial banks used in the analysis. The sample period is from 2001:Q1 to 2015:Q4. All financial variables are winsorized at $1 \%$ and $99 \%$ levels. Panel A shows the mean and median of our main variables, and presents tests of differences between public and private banks. Panel B provides the correlation between main variables.

Panel A: Mean and median

\begin{tabular}{|c|c|c|c|c|c|c|}
\hline & \multicolumn{3}{|c|}{ Mean } & \multicolumn{3}{|c|}{ Median } \\
\hline & Private & Public & t-test & Private & Public & Wilconxon test \\
\hline & (1) & $(2)$ & $(3)=(1)-(2)$ & (4) & (5) & $(6)=((4)-(5)$ \\
\hline ZSCORE & 42.060 & 51.408 & $-9.349 * * *$ & 33.563 & 39.143 & $-5.580 * * *$ \\
\hline SIZE & 13.357 & 14.617 & $-1.259 * * *$ & 13.210 & 14.222 & $-1.012 * * *$ \\
\hline CAPITAL & 0.091 & 0.095 & $-0.005 * * *$ & 0.087 & 0.091 & $-0.005 * * *$ \\
\hline EARNINGS & 0.015 & 0.015 & $-0.000 * *$ & 0.015 & 0.016 & $-0.000 * * *$ \\
\hline GROWTH & 0.019 & 0.021 & $-0.002 * * *$ & 0.014 & 0.014 & 0.000 \\
\hline LOAN & 0.654 & 0.660 & $-0.005^{* * *}$ & 0.671 & 0.676 & $-0.005^{* * *}$ \\
\hline NONINTEREST INCOMES & 0.219 & 0.250 & $-0.031 * * *$ & 0.194 & 0.222 & $-0.029 * * *$ \\
\hline
\end{tabular}

Panel B: Correlation between variables

\begin{tabular}{|l|l|l|l|c|c|}
\hline & ZSCORE & SIZE & CAPITAL & EARNINGS & GROWTH \\
\hline ZSCORE & & & \\
\hline SIZE & $0.0378^{* * *}$ & & & \\
\hline CAPITAL & $0.2295^{* * *}$ & $0.0501^{* * *}$ & & \\
\hline EARNINGS & $0.2234^{* * *}$ & $0.0667^{* * *}$ & $0.2562^{* * *}$ & 1 & \\
\hline GROWTH & $0.0879^{* * *}$ & $0.0135^{* * *}$ & $-0.0626^{* * *}$ & $0.0995^{* * *}$ & \\
\hline LOAN & $-0.0465^{* * *}$ & $-0.1247^{* * *}$ & $-0.2178^{* * *}$ & $0.0852^{* * *}$ & \\
\hline NONINTEREST INCOMES & $-0.0792^{* * *}$ & $0.3807^{* * *}$ & $0.0666^{* * *}$ & $0.1480^{* * *}$ & \\
\hline
\end{tabular}




\section{Table 3. Baseline Multivariate Analysis}

This table reports regression estimates of the relation between ZSCORE and listing status. The sample period is from 2001:Q1 to 2015:Q4. Panel A presents baseline models. The main independent variable is PUBLIC. Models (1) presents analysis with only PUBLIC and time fixed effects. Models (2) presents our baseline model, controlling for size, capital ratio, dummy loss, earnings, growth opportunities, loans ratio and noninterest incomes. Model (3) re-performs Model (2) with lag 12 of all explanatory variables. Model (4) presents the average analysis (one observation by bank). All regressions include time (quarter) fixed effects, except for Model (5). Panel B presents differences between accrual ZSCORE and predicted ZSCORE. All financial variables are winsorized at the $1 \%$ and $99 \%$ levels. ***, **, * indicate significance at the $1 \%$, $5 \%$, and $10 \%$ level respectively. Standard errors are clustered at the bank level. Numbers in parentheses are t-statistics.

Panel A: Baseline Models

\begin{tabular}{|c|c|c|c|c|c|}
\hline & \multicolumn{5}{|c|}{ Dependent variable = ZSCORE (Over 12 quarters) } \\
\hline & & $\begin{array}{c}\text { Baseline } \\
\text { model }\end{array}$ & Lag 12 & $\begin{array}{c}\text { Additional } \\
\text { variables }\end{array}$ & $\begin{array}{l}\text { Average } \\
\text { analysis }\end{array}$ \\
\hline & (1) & $(2)$ & (3) & (4) & (5) \\
\hline PUBLIC & $\begin{array}{c}10.155^{* * *} \\
(1.612)\end{array}$ & $\begin{array}{c}7.680 * * * \\
(1.618)\end{array}$ & $\begin{array}{c}7.586^{* * *} \\
(1.928)\end{array}$ & $\begin{array}{c}8.836^{* * *} \\
(1.597)\end{array}$ & $\begin{array}{c}10.276^{* * * *} \\
(1.718)\end{array}$ \\
\hline SIZE & & $\begin{array}{c}2.018 * * * \\
(0.546)\end{array}$ & $\begin{array}{c}3.629 * * * \\
(0.786)\end{array}$ & $\begin{array}{c}2.754 * * * \\
(0.638)\end{array}$ & $\begin{array}{c}2.405 * * * \\
(0.656)\end{array}$ \\
\hline CAPITAL & & $\begin{array}{c}216.535^{* * *} \\
(24.571)\end{array}$ & $\begin{array}{c}218.609 * * * \\
(28.963)\end{array}$ & $\begin{array}{c}261.547^{* * * *} \\
(22.507)\end{array}$ & $\begin{array}{c}270.723^{* * * *} \\
(25.306)\end{array}$ \\
\hline EARNINGS & & $\begin{array}{c}212.321^{* * *} \\
(72.759)\end{array}$ & $\begin{array}{c}359.566 * * * \\
(67.979)\end{array}$ & $\begin{array}{l}108.490^{*} \\
(58.275)\end{array}$ & $\begin{array}{c}560.949 * * * \\
(105.617)\end{array}$ \\
\hline GROWTH & & $\begin{array}{c}15.421 * * * \\
(5.547)\end{array}$ & $\begin{array}{c}12.748^{* *} \\
(6.008)\end{array}$ & $\begin{array}{c}4.335 \\
(5.395)\end{array}$ & $\begin{array}{l}97.418 * * \\
(38.442)\end{array}$ \\
\hline LOANS & & $\begin{array}{c}-20.237 * * * \\
(5.316)\end{array}$ & $\begin{array}{c}-36.770 * * * \\
(6.309)\end{array}$ & $\begin{array}{c}-23.357 * * * \\
(5.047)\end{array}$ & $\begin{array}{c}-32.480 * * * \\
(5.622)\end{array}$ \\
\hline DUMMY LOSS & & $\begin{array}{c}-23.569 * * * \\
(1.164)\end{array}$ & $\begin{array}{c}52.295 * * * \\
(6.599)\end{array}$ & $\begin{array}{c}-6.917 * * * \\
(1.006)\end{array}$ & $\begin{array}{c}54.310 * * * \\
(6.213)\end{array}$ \\
\hline NONINTEREST INCOMES & & $\begin{array}{c}-41.268 * * * \\
(4.656)\end{array}$ & $\begin{array}{c}-37.826 * * * \\
(5.443)\end{array}$ & $\begin{array}{c}-22.828^{* * * *} \\
(4.146)\end{array}$ & $\begin{array}{c}-52.935 * * * \\
(5.744)\end{array}$ \\
\hline NPL & & & & $\begin{array}{c}-228.586 * * * \\
(23.207)\end{array}$ & \\
\hline DEPOSITS & & & & $\begin{array}{c}25.224 * * * \\
(5.255)\end{array}$ & \\
\hline$\sigma($ EARNINGS $)$ & & & & $\begin{array}{c}-1,624.674^{* * *} \\
(79.784) \\
\end{array}$ & \\
\hline Constant & $\begin{array}{c}46.541 * * * \\
(0.963)\end{array}$ & $\begin{array}{c}19.741^{* *} \\
(8.542)\end{array}$ & $\begin{array}{c}-28.794 * * \\
(13.480)\end{array}$ & $\begin{array}{c}-2.250 \\
(10.657)\end{array}$ & $\begin{array}{c}-28.667 * * \\
(11.619)\end{array}$ \\
\hline QFE & Yes & Yes & Yes & Yes & Yes \\
\hline Observations & 45,924 & 43,814 & 36,693 & 34,363 & 2,067 \\
\hline Adj R2 & 0.126 & 0.211 & 0.216 & 0.333 & 0.196 \\
\hline N_clust & 2328 & 2314 & 1885 & 1832 & . \\
\hline
\end{tabular}


Panel B: Difference between actual ZSCORE and predicted ZSCORE

\begin{tabular}{|c|c|c|c|c|c|}
\hline & Full sample & $\begin{array}{c}\text { 1:1 matching w/o } \\
\text { replacement }\end{array}$ & $\begin{array}{c}\text { 1:1 matching with } \\
\text { replacement }\end{array}$ & Nearest neighbor $\mathrm{N}=2$ & Nearest neighbor $\mathrm{N}=3$ \\
\hline & $(1)$ & $(2)$ & (3) & $(4)$ & (5) \\
\hline Mean of difference & $6.782 * * *$ & $4.808 * * *$ & $4.023 * * *$ & $4.746 * * *$ & $4.983 * * *$ \\
\hline
\end{tabular}




\section{Table 4. Alternative Measures of Risks, Sampling and Estimation Methods}

This table reports regression estimates of the relation between ZSCORE and listing status. The sample period is from 2001:Q1 to 2015:Q4. The dependent variable is ZSCORE and the main independent variable is PUBLIC. Panel A presents estimations with alternative measures of risks. Panel B presents estimations with different samplings. We exclude top $10^{\text {th }}$ largest banks in Model (1), TBTF banks in Model (2). Models (3)-(5) present estimations with different bank size classes. Panel C presents alternative estimation methods: Weighted regression in Model (1), quantile regressions in Models (2)-(4), Newey-West in Model (5), Prais-Winsten in Model (6), Fama-MacBeth in Model (7) and two-way cluster in Model (8). All financial variables are winsorized at the $1 \%$ and $99 \%$ levels. ***, **, * indicate significance at the $1 \%, 5 \%$, and $10 \%$ level respectively. Standard errors are clustered at the bank level. Numbers in parentheses are t-statistics.

Panel A: Alternative measures of risks

\begin{tabular}{|c|c|c|c|c|c|c|}
\hline & $\begin{array}{c}\text { ZSCORE } \\
\text { over } 8 \\
\text { quarters }\end{array}$ & $\begin{array}{l}\text { ZSCORE } \\
\text { over } 16 \\
\text { quarters }\end{array}$ & $\begin{array}{l}\text { Abnormal } \\
\text { ZSCORE }\end{array}$ & NPL & $\begin{array}{l}\text { Tier } 1 \\
\text { ratio }\end{array}$ & $\begin{array}{l}\text { Costs of } \\
\text { deposits }\end{array}$ \\
\hline & (1) & (2) & (3) & (4) & (5) & (6) \\
\hline PUBLIC & $\begin{array}{c}13.117 * * * \\
(1.891)\end{array}$ & $\begin{array}{c}4.351^{* * *} \\
(1.570)\end{array}$ & $\begin{array}{c}7.680^{* * *} \\
(1.618)\end{array}$ & $\begin{array}{l}-0.000 \\
(0.001)\end{array}$ & $\begin{array}{l}0.002^{*} \\
(0.001)\end{array}$ & $\begin{array}{l}-0.028^{*} \\
(0.014)\end{array}$ \\
\hline SIZE & $\begin{array}{c}3.742 * * * \\
(0.709)\end{array}$ & $\begin{array}{l}1.049 * * \\
(0.522)\end{array}$ & $\begin{array}{c}2.018 * * * \\
(0.546)\end{array}$ & $\begin{array}{l}-0.000 \\
(0.000)\end{array}$ & $\begin{array}{c}-0.010^{* * *} \\
(0.001)\end{array}$ & $\begin{array}{c}-0.043^{* * *} \\
(0.005)\end{array}$ \\
\hline CAPITAL & $\begin{array}{c}297.847 * * * \\
(27.304)\end{array}$ & $\begin{array}{c}191.923 * * * \\
(23.590)\end{array}$ & $\begin{array}{c}216.535^{* * * *} \\
(24.571)\end{array}$ & $\begin{array}{l}-0.015 \\
(0.010)\end{array}$ & $\begin{array}{c}1.028 * * * \\
(0.028)\end{array}$ & $\begin{array}{l}-0.319 \\
(0.197)\end{array}$ \\
\hline EARNINGS & $\begin{array}{c}384.853 * * * \\
(90.927)\end{array}$ & $\begin{array}{c}291.022^{* * *} \\
(68.906)\end{array}$ & $\begin{array}{c}212.321 * * * \\
(72.759)\end{array}$ & $\begin{array}{c}-0.061 * * \\
(0.028)\end{array}$ & $\begin{array}{c}0.386 * * * \\
(0.070)\end{array}$ & $\begin{array}{c}-1.964 * * * \\
(0.756)\end{array}$ \\
\hline GROWTH & $\begin{array}{l}11.207^{*} \\
(6.740)\end{array}$ & $\begin{array}{c}14.774 * * * \\
(5.521)\end{array}$ & $\begin{array}{c}15.421^{* * *} \\
(5.547)\end{array}$ & $\begin{array}{c}-0.042 * * * \\
(0.003)\end{array}$ & $\begin{array}{c}-0.018 * * * \\
(0.005)\end{array}$ & $\begin{array}{c}0.129 * * * \\
(0.044)\end{array}$ \\
\hline LOANS & $\begin{array}{c}-22.063 * * * \\
(6.215)\end{array}$ & $\begin{array}{c}-23.742 * * * \\
(5.690)\end{array}$ & $\begin{array}{c}-20.237 * * * \\
(5.316)\end{array}$ & $\begin{array}{c}0.001 \\
(0.002)\end{array}$ & $\begin{array}{c}-0.152^{* * *} \\
(0.005)\end{array}$ & $\begin{array}{c}0.639 * * * \\
(0.050)\end{array}$ \\
\hline DUMMY LOSS & $\begin{array}{c}-27.956 * * * \\
(1.435)\end{array}$ & $\begin{array}{c}-18.275^{* * *} \\
(1.060)\end{array}$ & $\begin{array}{c}-23.569 * * * \\
(1.164)\end{array}$ & $\begin{array}{c}0.024 * * * \\
(0.001)\end{array}$ & $\begin{array}{l}-0.000 \\
(0.001)\end{array}$ & $\begin{array}{c}0.097 * * * \\
(0.013)\end{array}$ \\
\hline NONINTEREST INCOMES & $\begin{array}{c}-51.286 * * * \\
(5.560) \\
\end{array}$ & $\begin{array}{c}-30.713^{* * *} \\
(4.638)\end{array}$ & $\begin{array}{c}-41.268 * * * \\
(4.656)\end{array}$ & $\begin{array}{l}-0.001 \\
(0.002) \\
\end{array}$ & $\begin{array}{c}-0.005 \\
(0.005) \\
\end{array}$ & $\begin{array}{c}-0.144 * * * \\
(0.052) \\
\end{array}$ \\
\hline Constant & $\begin{array}{c}-6.786 \\
(10.832)\end{array}$ & $\begin{array}{l}31.591 * * * \\
(8.211)\end{array}$ & $\begin{array}{c}-16.872^{* *} \\
(8.542)\end{array}$ & $\begin{array}{c}0.012 * * * \\
(0.003)\end{array}$ & $\begin{array}{c}0.259 * * * \\
(0.009)\end{array}$ & $\begin{array}{c}-4.371 * * * \\
(0.081)\end{array}$ \\
\hline QFE & Yes & Yes & Yes & Yes & Yes & Yes \\
\hline Observations & 52,124 & 33,298 & 43,814 & 58,451 & 66,177 & 68,022 \\
\hline Adj R2 & 0.163 & 0.225 & 0.129 & 0.394 & 0.698 & 0.802 \\
\hline N_clust & 2575 & 1825 & 2314 & 2552 & 2813 & 2933 \\
\hline
\end{tabular}


$\underline{\text { Panel B: Alternative samplings }}$

\begin{tabular}{|c|c|c|c|c|c|}
\hline & $\begin{array}{c}\text { Exclude top } \\
\text { 10th largest } \\
\text { banks } \\
\end{array}$ & $\begin{array}{l}\text { Exclude } \\
\text { TBTF }\end{array}$ & Assets $<\$ 1 B$ & $\$ 1 B<$ Assets $<\$ 5 B$ & Assets $>\$ 5 B$ \\
\hline & $(1)$ & $(2)$ & (3) & $(4)$ & (5) \\
\hline PUBLIC & $\begin{array}{c}6.144 * * * \\
(1.733)\end{array}$ & $\begin{array}{c}7.709 * * * \\
(1.617)\end{array}$ & $\begin{array}{l}4.626^{* *} \\
(2.098)\end{array}$ & $\begin{array}{c}8.850^{* * * *} \\
(2.599)\end{array}$ & $\begin{array}{l}7.372^{*} \\
(4.285)\end{array}$ \\
\hline SIZE & $\begin{array}{c}4.246 * * * \\
(0.965)\end{array}$ & $\begin{array}{c}1.972 * * * \\
(0.542)\end{array}$ & $\begin{array}{c}10.302 * * * \\
(1.781)\end{array}$ & $\begin{array}{l}-2.105 \\
(2.623)\end{array}$ & $\begin{array}{l}-0.592 \\
(1.470)\end{array}$ \\
\hline CAPITAL & $\begin{array}{c}231.902^{* * *} \\
(26.478)\end{array}$ & $\begin{array}{c}217.916 * * * \\
(24.557)\end{array}$ & $\begin{array}{c}302.918 * * * \\
(26.825)\end{array}$ & $\begin{array}{c}142.239 * * * \\
(53.989)\end{array}$ & $\begin{array}{l}105.126^{*} \\
(63.130)\end{array}$ \\
\hline EARNINGS & $\begin{array}{c}177.613^{* *} \\
(75.962)\end{array}$ & $\begin{array}{c}210.269 * * * \\
(72.311)\end{array}$ & $\begin{array}{c}66.801 \\
(75.990)\end{array}$ & $\begin{array}{c}432.196 * * * \\
(147.609)\end{array}$ & $\begin{array}{c}198.306 \\
(167.745)\end{array}$ \\
\hline GROWTH & $\begin{array}{c}11.964 * * \\
(5.606)\end{array}$ & $\begin{array}{c}16.748 * * * \\
(5.588)\end{array}$ & $\begin{array}{c}14.100 * * \\
(6.775)\end{array}$ & $\begin{array}{l}-2.040 \\
(8.911)\end{array}$ & $\begin{array}{c}33.701 * * \\
(14.376)\end{array}$ \\
\hline LOANS & $\begin{array}{c}-24.857 * * * \\
(5.487)\end{array}$ & $\begin{array}{c}-20.140 * * * \\
(5.294)\end{array}$ & $\begin{array}{c}-24.042 * * * \\
(6.038)\end{array}$ & $\begin{array}{c}-25.708^{* *} \\
(10.623)\end{array}$ & $\begin{array}{c}1.213 \\
(15.975)\end{array}$ \\
\hline DUMMY LOSS & $\begin{array}{c}-23.195 * * * \\
(1.233)\end{array}$ & $\begin{array}{c}-23.477 * * * \\
(1.160)\end{array}$ & $\begin{array}{c}-21.715^{* * *} \\
(1.308)\end{array}$ & $\begin{array}{c}-23.401 * * * \\
(2.361)\end{array}$ & $\begin{array}{c}-24.817 * * * \\
(2.962)\end{array}$ \\
\hline NONINTEREST INCOMES & $\begin{array}{c}-38.041 * * * \\
(4.981)\end{array}$ & $\begin{array}{c}-40.690 * * * \\
(4.642)\end{array}$ & $\begin{array}{c}-36.423 * * * \\
(4.998)\end{array}$ & $\begin{array}{c}-39.163 * * * \\
(8.773)\end{array}$ & $\begin{array}{c}-43.316^{* * *} \\
(12.998)\end{array}$ \\
\hline Constant & $\begin{array}{c}-7.777 \\
(13.860)\end{array}$ & $\begin{array}{c}20.045^{* *} \\
(8.506)\end{array}$ & $\begin{array}{c}-91.655 * * * \\
(23.338)\end{array}$ & $\begin{array}{c}86.979 * * \\
(36.559)\end{array}$ & $\begin{array}{l}62.888 * * \\
(28.341)\end{array}$ \\
\hline QFE & Yes & Yes & Yes & Yes & Yes \\
\hline Observations & 38,500 & 43,350 & 25,136 & 13,291 & 5,387 \\
\hline Adj R2 & 0.216 & 0.211 & 0.225 & 0.226 & 0.231 \\
\hline N_clust & 2137 & 2313 & 1754 & 654 & 590 \\
\hline
\end{tabular}


Panel C: Alternative estimation methods

\begin{tabular}{|c|c|c|c|c|c|c|c|c|}
\hline & $\begin{array}{l}\text { Weighted } \\
\text { regressions }\end{array}$ & Q25 & Q50 & Q75 & Newey-West & Prais-Winsten & $\begin{array}{c}\text { Fama- } \\
\text { MacBeth }\end{array}$ & $\begin{array}{c}\text { Two-way } \\
\text { cluster }\end{array}$ \\
\hline & $(1)$ & $(2)$ & (3) & (4) & (5) & (6) & $(7)$ & $(8)$ \\
\hline PUBLIC & $\begin{array}{l}\text { 7.067* } \\
(4.128)\end{array}$ & $\begin{array}{l}0.637 * * \\
(0.325)\end{array}$ & $\begin{array}{c}4.395 * * * \\
(0.405)\end{array}$ & $\begin{array}{c}9.550 * * * \\
(0.634)\end{array}$ & $\begin{array}{c}8.189 * * * \\
(0.716)\end{array}$ & $\begin{array}{c}4.353 * * * \\
(0.957)\end{array}$ & $\begin{array}{c}6.640^{* * *} \\
(1.458)\end{array}$ & $\begin{array}{c}8.189 * * * \\
(1.837)\end{array}$ \\
\hline SIZE & $\begin{array}{l}1.285 \\
(1.286)\end{array}$ & $\begin{array}{c}0.117 \\
(0.126)\end{array}$ & $\begin{array}{c}0.578 * * * \\
(0.157)\end{array}$ & $\begin{array}{c}2.560 * * * \\
(0.245)\end{array}$ & $\begin{array}{c}0.965 * * * \\
(0.263)\end{array}$ & $\begin{array}{l}-0.098 \\
(0.470)\end{array}$ & $\begin{array}{l}1.811^{* *} \\
(0.725)\end{array}$ & $\begin{array}{c}0.965 \\
(0.674)\end{array}$ \\
\hline CAPITAL & $\begin{array}{c}88.264 \\
(63.403)\end{array}$ & $\begin{array}{c}112.950^{* * *} \\
(5.090)\end{array}$ & $\begin{array}{c}200.410 * * * \\
(6.334)\end{array}$ & $\begin{array}{c}327.127 * * * \\
(9.917)\end{array}$ & $\begin{array}{c}201.025^{* * * *} \\
(10.789)\end{array}$ & $\begin{array}{c}83.986 * * * \\
(8.253)\end{array}$ & $\begin{array}{c}221.052^{* * * *} \\
(18.582)\end{array}$ & $\begin{array}{c}201.025 * * * \\
(25.447)\end{array}$ \\
\hline EARNINGS & $\begin{array}{c}82.548 \\
(233.159)\end{array}$ & $\begin{array}{c}103.953^{* * *} \\
(19.451)\end{array}$ & $\begin{array}{c}180.676^{* * *} \\
(24.201)\end{array}$ & $\begin{array}{c}225.467 * * * \\
(37.893)\end{array}$ & $\begin{array}{c}309.318^{* * * *} \\
(33.138)\end{array}$ & $\begin{array}{l}9.552^{*} \\
(5.195)\end{array}$ & $\begin{array}{c}171.828 * * * \\
(42.968)\end{array}$ & $\begin{array}{c}309.318 * * * \\
(76.310)\end{array}$ \\
\hline GROWTH & $\begin{array}{c}40.837 * * * \\
(13.175)\end{array}$ & $\begin{array}{c}27.997 * * * \\
(3.345)\end{array}$ & $\begin{array}{c}27.856 * * * \\
(4.162)\end{array}$ & $\begin{array}{c}13.721^{* *} \\
(6.517)\end{array}$ & $\begin{array}{c}41.299 * * * \\
(4.081)\end{array}$ & $\begin{array}{c}2.799 * * \\
(1.147)\end{array}$ & $\begin{array}{l}23.093 * * \\
(10.493)\end{array}$ & $\begin{array}{c}41.299 * * * \\
(9.331)\end{array}$ \\
\hline LOANS & $\begin{array}{c}23.703 \\
(17.066)\end{array}$ & $\begin{array}{c}-8.177 * * * \\
(1.191)\end{array}$ & $\begin{array}{c}-16.651^{* * *} \\
(1.482)\end{array}$ & $\begin{array}{c}-22.440^{* * * *} \\
(2.321)\end{array}$ & $\begin{array}{c}-17.314 * * * \\
(2.314)\end{array}$ & $\begin{array}{l}-0.047 \\
(2.147)\end{array}$ & $\begin{array}{c}-21.630 * * * \\
(3.114)\end{array}$ & $\begin{array}{c}-17.314^{* * *} \\
(5.458)\end{array}$ \\
\hline DUMMY LOSS & $\begin{array}{c}-17.864 * * * \\
(3.416)\end{array}$ & $\begin{array}{c}-9.611 * * * \\
(0.564)\end{array}$ & $\begin{array}{c}-16.510 * * * \\
(0.702)\end{array}$ & $\begin{array}{c}-23.829 * * * \\
(1.099)\end{array}$ & $\begin{array}{c}-31.525^{* * *} \\
(0.575)\end{array}$ & $\begin{array}{c}-0.498 * * * \\
(0.093)\end{array}$ & $\begin{array}{c}-28.871 * * * \\
(2.577)\end{array}$ & $\begin{array}{c}-31.525^{* * * *} \\
(1.854)\end{array}$ \\
\hline NONINTEREST INCOMES & $\begin{array}{c}-42.073 * * * \\
(15.373)\end{array}$ & $\begin{array}{c}-16.802 * * * \\
(1.160)\end{array}$ & $\begin{array}{c}-27.402^{* * *} \\
(1.444)\end{array}$ & $\begin{array}{c}-40.570^{* * *} \\
(2.260)\end{array}$ & $\begin{array}{c}-41.348 * * * \\
(2.093)\end{array}$ & $\begin{array}{l}-1.011 \\
(0.656)\end{array}$ & $\begin{array}{c}-40.957 * * * \\
(4.335)\end{array}$ & $\begin{array}{c}-41.348^{* * * *} \\
(5.404)\end{array}$ \\
\hline Constant & $\begin{array}{c}12.004 \\
(26.105)\end{array}$ & $\begin{array}{c}19.817 * * * \\
(2.036)\end{array}$ & $\begin{array}{c}27.501^{* * * *} \\
(2.534)\end{array}$ & $\begin{array}{c}17.892 * * * \\
(3.967)\end{array}$ & $\begin{array}{c}29.276 * * * \\
(4.171)\end{array}$ & $\begin{array}{c}33.953 * * * \\
(6.735)\end{array}$ & $\begin{array}{l}19.702^{*} \\
(9.892)\end{array}$ & $\begin{array}{c}29.276^{* * * *} \\
(9.922)\end{array}$ \\
\hline QFE & Yes & Yes & Yes & Yes & Yes & Yes & Yes & Yes \\
\hline Observations & 43,350 & 43,814 & 43,814 & 43,814 & 43,814 & 43,814 & 43,814 & 43,814 \\
\hline $\begin{array}{l}\text { Adj R2 } \\
\mathrm{N} \text { clust }\end{array}$ & $\begin{array}{c}0.281 \\
2313\end{array}$ & & . & , & . & 0.040 & 0.165 & 0.149 \\
\hline
\end{tabular}




\section{Table 5. Endogeneity concerns}

This table reports regression estimates of the relation between ZSCORE and listing status. The sample period is from 2001:Q1 to 2015:Q4. The dependent variable is ZSCORE and the main independent variable is PUBLIC. Models (1)-(2) reports results from PSM with N=1 without and with replacement, respectively. Model (3) reports results from PSM with N=2 and Model (4) reports results from PSM with $\mathrm{N}=3$, respectively. Models (5)-(6) present estimations of Heckman selection model. Models (7)-(8) present estimations of IV estimations. All financial variables are winsorized at the 1\% and 99\% levels. *****,* indicate significance at the $1 \%, 5 \%$, and $10 \%$ level respectively. Standard errors are clustered at the bank level. Numbers in parentheses are $\mathrm{t}$-statistics.

Panel A: Propensity-score matching, Heckman selection and Instrument variables approach

\begin{tabular}{|c|c|c|c|c|c|c|c|c|}
\hline & \multicolumn{4}{|c|}{ Psm } & \multicolumn{2}{|c|}{ Heckman selection } & \multicolumn{2}{|c|}{ IV } \\
\hline & $\begin{array}{c}\text { 1:1 matching } \\
\text { without } \\
\text { replacement }\end{array}$ & $\begin{array}{l}\text { 1:1 matching } \\
\text { with } \\
\text { replacement }\end{array}$ & $\begin{array}{c}\text { Nearest } \\
\text { neighbor } \mathrm{N}=2\end{array}$ & $\begin{array}{c}\text { Nearest } \\
\text { neighbor } \mathrm{N}=3\end{array}$ & 1rst stage & 2nd stage & 1rst stage & 2nd stage \\
\hline & (1) & (2) & (3) & (4) & (5) & (6) & (7) & (8) \\
\hline PUBLIC & $\begin{array}{l}4.430 * * \\
(1.897)\end{array}$ & $\begin{array}{l}3.751 * * \\
(1.849)\end{array}$ & $\begin{array}{l}4.388 * * \\
(1.804)\end{array}$ & $\begin{array}{c}4.695 * * * \\
(1.801)\end{array}$ & & $\begin{array}{c}9.867 * * \\
(4.014)\end{array}$ & & $\begin{array}{c}19.804 * * * \\
(4.242)\end{array}$ \\
\hline SIZE & $\begin{array}{c}0.901 \\
(0.733)\end{array}$ & $\begin{array}{l}1.752 * * \\
(0.740)\end{array}$ & $\begin{array}{l}1.496 * * \\
(0.711)\end{array}$ & $\begin{array}{l}1.603 * * \\
(0.708)\end{array}$ & $\begin{array}{c}0.407 * * * \\
(0.005)\end{array}$ & $\begin{array}{l}1.019 \\
(0.810)\end{array}$ & $\begin{array}{c}0.122 * * * \\
(0.009)\end{array}$ & $\begin{array}{c}0.252 \\
(0.853)\end{array}$ \\
\hline CAPITAL & $\begin{array}{c}155.577 * * * \\
(33.383)\end{array}$ & $\begin{array}{c}169.203^{* * *} \\
(33.670)\end{array}$ & $\begin{array}{c}191.320 * * * \\
(32.231)\end{array}$ & $\begin{array}{c}202.871^{* * * *} \\
(32.524)\end{array}$ & $\begin{array}{c}2.495^{* * * *} \\
(0.213)\end{array}$ & $\begin{array}{c}208.445^{* * *} \\
(25.783)\end{array}$ & $\begin{array}{c}0.707 * * * \\
(0.243)\end{array}$ & $\begin{array}{c}203.389 * * * \\
(25.747)\end{array}$ \\
\hline EARNINGS & $\begin{array}{c}578.827 * * * \\
(109.340)\end{array}$ & $\begin{array}{c}582.112 * * * \\
(110.532)\end{array}$ & $\begin{array}{c}480.109 * * * \\
(103.598)\end{array}$ & $\begin{array}{c}432.293 * * * \\
(98.735)\end{array}$ & $\begin{array}{c}-6.469 * * * \\
(0.827)\end{array}$ & $\begin{array}{c}260.286 * * * \\
(73.224)\end{array}$ & $\begin{array}{l}-1.404^{*} \\
(0.804)\end{array}$ & $\begin{array}{c}244.812 * * * \\
(73.285)\end{array}$ \\
\hline GROWTH & $\begin{array}{l}-9.097 \\
(9.225)\end{array}$ & $\begin{array}{c}3.449 \\
(10.463)\end{array}$ & $\begin{array}{l}-2.922 \\
(9.415)\end{array}$ & $\begin{array}{c}2.319 \\
(8.887)\end{array}$ & $\begin{array}{c}0.403 * * * \\
(0.133)\end{array}$ & $\begin{array}{c}13.047 * * \\
(5.610)\end{array}$ & $\begin{array}{c}0.072 \\
(0.064)\end{array}$ & $\begin{array}{c}16.247 * * * \\
(5.647)\end{array}$ \\
\hline LOANS & $\begin{array}{c}-31.816^{* * *} \\
(9.165)\end{array}$ & $\begin{array}{c}-32.924 * * * \\
(9.299)\end{array}$ & $\begin{array}{c}-30.041 * * * \\
(8.467)\end{array}$ & $\begin{array}{c}-26.695 * * * \\
(7.986)\end{array}$ & $\begin{array}{c}1.115^{* * * *} \\
(0.051)\end{array}$ & $\begin{array}{c}-22.588 * * * \\
(5.306)\end{array}$ & $\begin{array}{c}0.262 * * * \\
(0.063)\end{array}$ & $\begin{array}{c}-24.197 * * * \\
(5.444)\end{array}$ \\
\hline DUMMY LOSS & $\begin{array}{c}-23.050^{* * *} \\
(1.586)\end{array}$ & $\begin{array}{c}-21.829 * * * \\
(1.663)\end{array}$ & $\begin{array}{c}-23.527 * * * \\
(1.546)\end{array}$ & $\begin{array}{c}-23.502 * * * \\
(1.462)\end{array}$ & $\begin{array}{c}-0.054^{* *} \\
(0.025)\end{array}$ & $\begin{array}{c}-23.587 * * * \\
(1.166)\end{array}$ & $\begin{array}{l}-0.011 \\
(0.015)\end{array}$ & $\begin{array}{c}-23.659 * * * \\
(1.158)\end{array}$ \\
\hline NONINTEREST INCOMES & $\begin{array}{c}-46.788 * * * \\
(7.152)\end{array}$ & $\begin{array}{c}-52.186 * * * \\
(7.288)\end{array}$ & $\begin{array}{c}-49.382 * * * \\
(6.764)\end{array}$ & $\begin{array}{c}-48.200 * * * \\
(6.383)\end{array}$ & $\begin{array}{c}0.018 \\
(0.049)\end{array}$ & $\begin{array}{c}-41.165 * * * \\
(4.738)\end{array}$ & $\begin{array}{l}-0.002 \\
(0.059)\end{array}$ & $\begin{array}{c}-41.290 * * * \\
(4.846)\end{array}$ \\
\hline FRACTION OF LISTED BANKS & & & & & $\begin{array}{c}2.986 * * * \\
(0.033)\end{array}$ & & $\begin{array}{c}0.840^{* * *} \\
(0.048)\end{array}$ & \\
\hline IMR & & & & & & $\begin{array}{c}-9.919 * * * \\
(2.817)\end{array}$ & & \\
\hline PUBLIC * IMR & & & & & & $\begin{array}{c}13.166^{* * * *} \\
(3.289)\end{array}$ & & \\
\hline Constant & $\begin{array}{c}49.354 * * * \\
(12.464)\end{array}$ & $\begin{array}{c}38.930 * * * \\
(12.563)\end{array}$ & $\begin{array}{c}38.591 * * * \\
(11.919)\end{array}$ & $\begin{array}{c}33.839 * * * \\
(11.771)\end{array}$ & $\begin{array}{c}-7.872 * * * \\
(0.089)\end{array}$ & $\begin{array}{c}31.166^{* * * *} \\
(11.693)\end{array}$ & $\begin{array}{c}-1.791 * * * \\
(0.126)\end{array}$ & $\begin{array}{c}43.819 * * * \\
(12.137)\end{array}$ \\
\hline QFE & Yes & Yes & Yes & Yes & Yes & Yes & Yes & Yes \\
\hline Observations & 13,792 & 8,294 & 11,752 & 13,727 & 68,114 & 43,251 & 68,114 & 43,251 \\
\hline Adj R2 & 0.212 & 0.226 & 0.219 & 0.217 & & 0.213 & 0.306 & 0.207 \\
\hline N_clust & 1539 & 1455 & 1624 & 1706 & . & 2308 & 2933 & 2308 \\
\hline
\end{tabular}


Panel B: Transition samples: Private to Public: Going IPO

Private to public (Going IPO)

ZSCORE before IPO (a)

ZSCORE after IPO (b)

Mean difference $=(\mathrm{b})$ - $(\mathrm{a})$
(1)

$[-4 ;+4]$

47.093

48.553

1.460
(2)

$[-8 ;+8]$

46.736

50.037

3.301*
(3)

[-12;+12]

46.815

50.405

$3.586 * *$
(4) $[-16 ;+16]$

47.365

50.272

2.907* 
Panel C: Transition samples: Public to Private: Going private

\begin{tabular}{lcccc}
\hline Public to private (Going Private) & $(1)$ & $(2)$ & $(3)$ & $(4)$ \\
\cline { 2 - 5 } & {$[-4 ;+4]$} & {$[-8 ;+8]$} & {$[-12 ;+12]$} & {$[-16 ;+16]$} \\
\hline ZSCORE before go private (a) & 28.764 & 32.31 & 35.108 & 37.586 \\
ZSCORE after go private (b) & 17.817 & 18.28 & 17.561 & 20.945 \\
\hline Mean difference = (b) - (a) & $-10.946^{* *}$ & $-14.029^{* * *}$ & $-17.547^{* * *}$ & $-16.641^{* * *}$ \\
\hline
\end{tabular}


Table 6. The Effects of The Financial Crises

This table reports regression estimates of the relation between ZSCORE and listing status. The sample period is from 2001:Q1 to 2015:Q4. The dependent variable is ZSCORE and the main independent variable is PUBLIC X is Core deposits in Model (2), Subordinated debts in Model (3), and Regulatory pressure in Model (4). All regressions include time (quarter) fixed effects. All financial variables

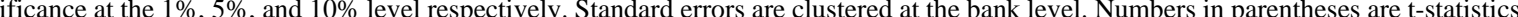
Panel A: Difference of actual ZSCORE during crisis versus predicted ZSCORE

\begin{tabular}{|c|c|c|c|c|c|}
\hline \multirow[t]{2}{*}{ Mean of difference } & Full sample & $\begin{array}{c}\text { 1:1 matching } \\
\text { w/o replacement }\end{array}$ & $\begin{array}{c}1: 1 \text { matching } \\
\text { with replacement }\end{array}$ & $\begin{array}{c}\text { Nearest neighbor } \\
\mathrm{N}=2\end{array}$ & $\begin{array}{c}\begin{array}{c}\text { Nearest neighbor } \\
\mathrm{N}=3\end{array} \\
\end{array}$ \\
\hline & (1) & $(2)$ & (3) & (4) & (5) \\
\hline Private banks & $-1.748 * * *$ & $-1.329 *$ & $-4.288 * * *$ & $-3.405^{* * *}$ & $-3.888 * * *$ \\
\hline Public banks & $-11.882 * * *$ & $-7.705^{* * *}$ & $-7.567 * * *$ & $-7.867 * * *$ & $-6.531^{* * *}$ \\
\hline
\end{tabular}


Panel B:

\begin{tabular}{|c|c|c|c|c|}
\hline & Full sample & $\mathrm{X}=$ Core deposits & $\begin{array}{c}\mathrm{X}=\text { Subordinated } \\
\text { debts }\end{array}$ & $\begin{array}{c}\mathrm{X}=\text { Regulatory } \\
\text { pressure }\end{array}$ \\
\hline & $(1)$ & $(2)$ & $(3)$ & $(4)$ \\
\hline PUBLIC & $\begin{array}{c}9.338 * * * \\
(1.667)\end{array}$ & $\begin{array}{c}1.347 \\
(8.520)\end{array}$ & $\begin{array}{c}8.565^{* * *} \\
(1.801)\end{array}$ & $\begin{array}{c}6.772 * * * \\
(1.891)\end{array}$ \\
\hline PUBLIC * CRISIS & $\begin{array}{c}-9.433 * * * \\
(1.540)\end{array}$ & $\begin{array}{c}-23.572 * * * \\
(6.815)\end{array}$ & $\begin{array}{c}-9.279 * * * \\
(1.639)\end{array}$ & $\begin{array}{c}-7.136^{* * *} \\
(1.731)\end{array}$ \\
\hline PUBLIC * X & & $\begin{array}{c}11.802 \\
(12.763)\end{array}$ & $\begin{array}{l}-480.544 \\
(470.007)\end{array}$ & $\begin{array}{l}8.805 * * * \\
(2.779)\end{array}$ \\
\hline PUBLIC * $\mathrm{X} *$ CRISIS & & $\begin{array}{c}25.458 * * \\
(11.221)\end{array}$ & $\begin{array}{l}-104.603 \\
(439.333)\end{array}$ & $\begin{array}{l}-8.972 * * * \\
(2.720)\end{array}$ \\
\hline $\mathrm{X}$ & & $\begin{array}{l}30.299 * * * \\
(6.429)\end{array}$ & $\begin{array}{l}-297.611 \\
(298.433)\end{array}$ & $\begin{array}{c}-7.677^{* * *} \\
(1.375)\end{array}$ \\
\hline SIZE & $\begin{array}{c}1.979 * * * \\
(0.546)\end{array}$ & $\begin{array}{c}3.458 * * * \\
(0.718)\end{array}$ & $\begin{array}{c}2.854 * * * \\
(0.698)\end{array}$ & $\begin{array}{c}2.379 * * * \\
(0.575)\end{array}$ \\
\hline CAPITAL & $\begin{array}{c}217.831^{* * *} \\
(24.589)\end{array}$ & $\begin{array}{c}241.373 * * * \\
(25.922)\end{array}$ & $\begin{array}{c}237.190 * * * \\
(25.821)\end{array}$ & $\begin{array}{c}188.792 * * * \\
(26.916)\end{array}$ \\
\hline EARNINGS & $\begin{array}{c}209.168 * * * \\
(72.652)\end{array}$ & $\begin{array}{c}174.520 * * \\
(69.212)\end{array}$ & $\begin{array}{c}162.617 * * \\
(73.974)\end{array}$ & $\begin{array}{c}200.766 * * * \\
(72.268)\end{array}$ \\
\hline GROWTH & $\begin{array}{c}15.514 * * * \\
(5.549)\end{array}$ & $\begin{array}{l}25.088 * * * \\
(5.865)\end{array}$ & $\begin{array}{l}17.762 * * * \\
(5.700)\end{array}$ & $\begin{array}{c}18.336 * * * \\
(5.494)\end{array}$ \\
\hline LOANS & $\begin{array}{c}-20.187 * * * \\
(5.312)\end{array}$ & $\begin{array}{c}-22.285^{* * *} \\
(5.424)\end{array}$ & $\begin{array}{c}-20.394 * * * \\
(5.554)\end{array}$ & $\begin{array}{c}-15.640 * * * \\
(5.549)\end{array}$ \\
\hline DUMMY LOSS & $\begin{array}{c}-23.473 * * * \\
(1.160)\end{array}$ & $\begin{array}{c}-21.830 * * * \\
(1.141)\end{array}$ & $\begin{array}{l}-23.488 * * * \\
(1.204)\end{array}$ & $\begin{array}{c}-22.505^{* * * *} \\
(1.125)\end{array}$ \\
\hline NONINTEREST INCOMES & $\begin{array}{c}-41.310 * * * \\
(4.661)\end{array}$ & $\begin{array}{c}-36.087 * * * \\
(4.820) \\
\end{array}$ & $\begin{array}{c}-41.925 * * * \\
(4.944) \\
\end{array}$ & $\begin{array}{c}-39.948 * * * \\
(4.659) \\
\end{array}$ \\
\hline Constant & $\begin{array}{c}19.771^{* *} \\
(8.544)\end{array}$ & $\begin{array}{l}-21.394 * \\
(11.436)\end{array}$ & $\begin{array}{c}8.224 \\
(10.170)\end{array}$ & $\begin{array}{l}15.919 * \\
(8.779)\end{array}$ \\
\hline QFE & Yes & Yes & Yes & Yes \\
\hline $\begin{array}{l}\text { Observations } \\
\text { Adj R2 } \\
\text { N_clust }\end{array}$ & $\begin{array}{c}43,814 \\
0.213 \\
2314\end{array}$ & $\begin{array}{c}38,087 \\
0.234 \\
2020\end{array}$ & $\begin{array}{l}42,390 \\
0.219 \\
2223\end{array}$ & $\begin{array}{c}43,427 \\
0.220 \\
2232\end{array}$ \\
\hline
\end{tabular}

